\title{
أحطاهو المرأة
}

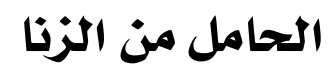

في الفقل الإسلامي من الرناي

د. عائشة سلطان الهرزوقي
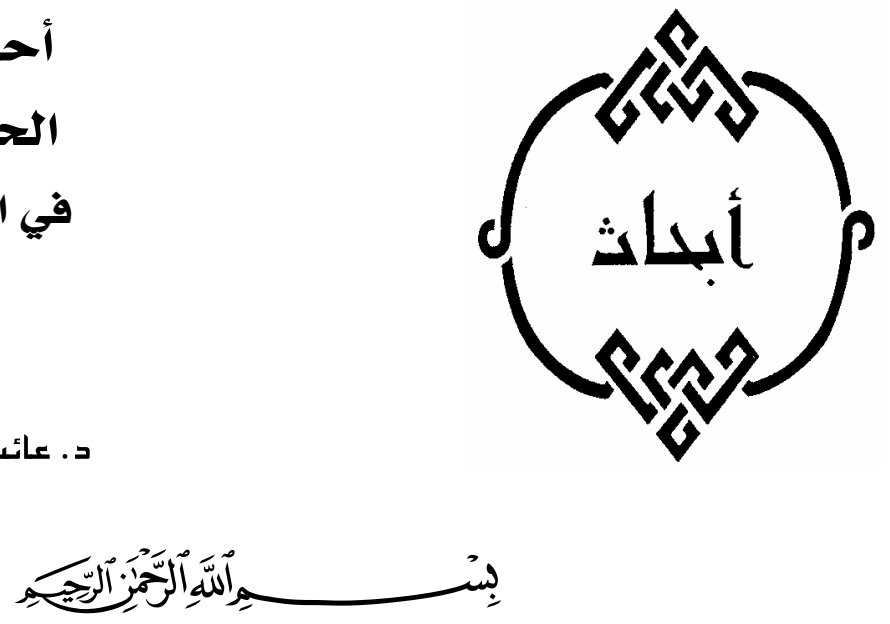

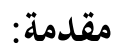

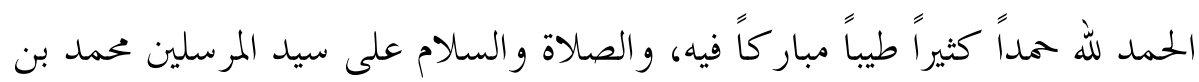
عبد الله وعلى آله وصحبه أجمعين، وبعد:

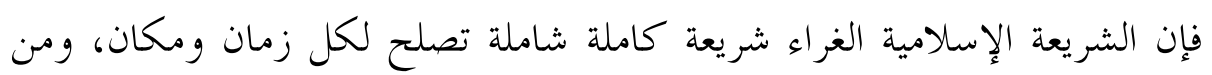

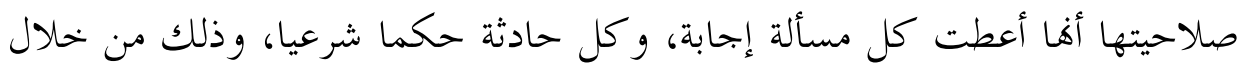

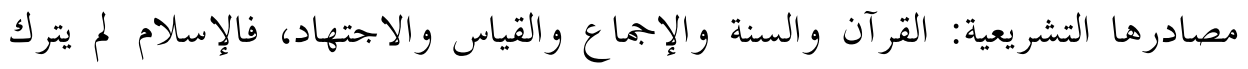

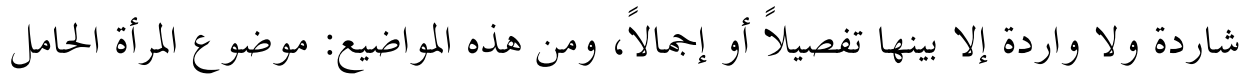

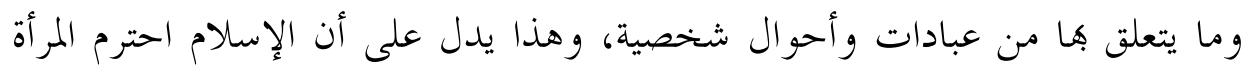

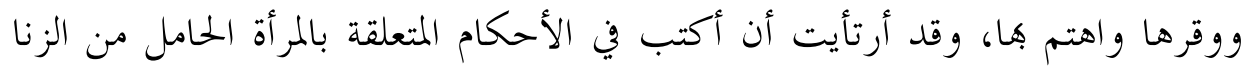
من ناحية الأحو ال الشخصية فقط دون العبادات؛ لأن من شأن ذلك أن يطيل البحث. وقد قسمت هذا البحث إلى المباحث التالية بعد هذه المقدمة الموجزة:

$$
\text { (") قسم الشريعة والدراسات الإسامية - كلية القانون - جامعة الإمارات. }
$$


المبحث الأول: نكاح المرأة الحامل وملاعنتها، وفيه ثلاثة مطالب:

المطلب الأول: نكاح المرأة الزانية إذا كانت حاملاً.

المطلب الثاني: ملاعنة المرأة الحامل.

المطلب الثالث: حكم إذن المرأة للطبيب بالإجهاض.

المبحث الثاني: نفقة المرأة الحامل، وفيه أربعة مطالب:

المطلب الأول: نفقة المرأة الحامل المطلقة.

المطلب الثاني: نفقة المرأة الحامل المتوفى عنها زوجها.

المطلب الثالث: نفقة المرأة الحامل في شبهة.

المطلب الرابع: نفقة المرأة الحامل الناشز.

المبحث الثالث: أكثر الحمل و أقله، وفيه مطلبان:

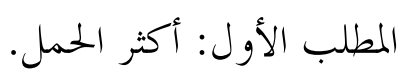

المطلب الثاني: أقل الحمل.

المبحث الرابع: عدة المرأة الحامل، وفيه مطلبان:

المطلب الأول: عدة المرأة الحامل المتوفى عنها زوجها.

المطلب الثاني: أحوال الحمل الذي تنقضي به العدة.

تم الخاتمة، وفهرس المصادر و المر اجع. 


\section{المبحث الأول}

\section{نكاح المرأة الحامل وملاعنتها}

اهتم الإسلام اهتماماً كبيراً بالأسرة، فركز على أن تكون الأسرة قوية متمسكة بالدين والأخلاق؛ لأن الأسر هي روافد الممجتمع، فإن كانت الروافد قوية ونظيفة

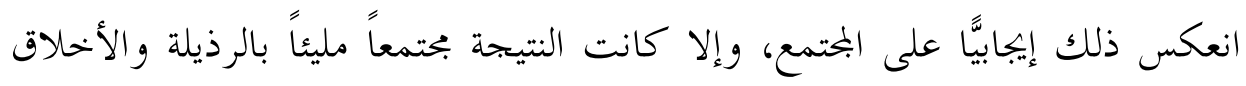

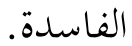

ومن ضمن اهتمامات الإســلام اهتمامه بالجلنين ونسبه؛ لذا حرم نكـــاح المـــــأة

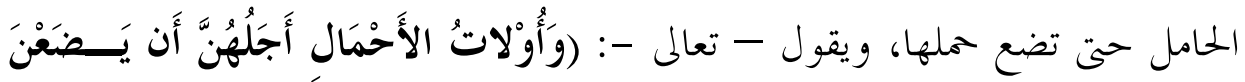

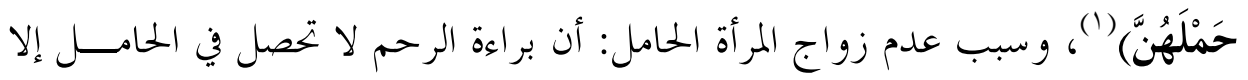
بوضع الحمل؛ لذا لا بد أن تضع المرأة حملها حتى تنتهي عدها وتتزوج من آخر. فلا بد أن تثبت حقيقة وهي: أن الإسلام حرم بعض السلوكيات لآثارها السيئة على الجختمع: كالزنا ومقدماته، فحرم- سبحانه- الاختلاط و الخلوة وعدم الاستئذان، وحرم خروج المرأة دون حجاب وغير ذلك؛ لأن هذه السلوكيات مقدمات إلى مفاسد عظيمة، وقد قال الفقهاء.مصدر سد الذرائع وتوسعو ا فيه؛ لكي لا يؤول الأمر إلى مفسدة عظيمة، فيقول ابن القيم - رحمه الله-: (لما كانت المقاصد لا يتوصل إليها إلا بأسباب وطرق تفضي إليها، كانت طرقها وأسباها تابعة لها معتبرة هها، فوسائل المحرمات والمعاصي في كراهتها، والمنع منها بحسب إفضائها إلى غايتها وارتباطها هها، ووسائل الطاعات والقربات في محبتها، والإذن فيها بحسب إفضائها إلى غايتها، فوسيلة المقصود تابعة للمقصود و كلاهما مقصود، ولكنه مقصود قصد الغايات، وهي مقصودة 
قصد الوسائل).

لقد ركز الله- سبحانه وتعالى - في الآيات الكريمة على حرمة الزنا، كما وحث على الفضيلة، ففي سورة المؤمنون ذكر الله أوصافاً للمؤمنين ومدحهم بقوله - تعالى -

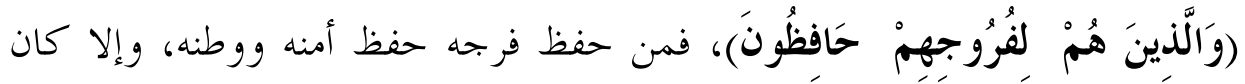
المعول هدم لهذا البحتمع، والمسألة المطروحة هنا هي: هل يجوز الزواج بالمرأة الحامل من

\section{المطلب الأول: نكاح المرأة الز انية إذا كانت حاملاً}

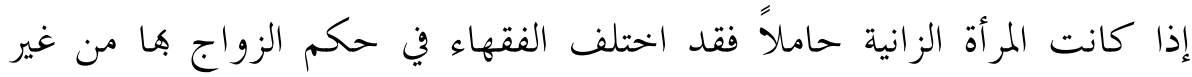
الزاني، وهذا الاختلاف كالآتي:

القول الأول: لا يبوز العقد عليها، ونكاح الحامل باطل (1) ويحرم، ولا ينكحها

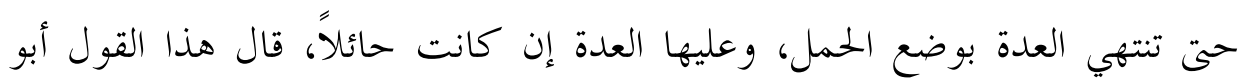

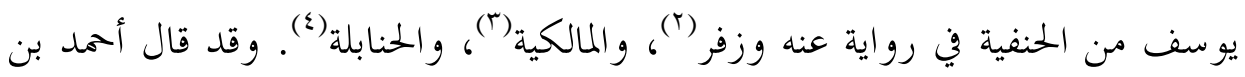

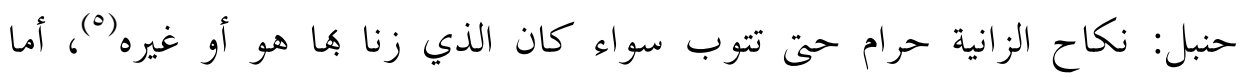
بالنسبة للز انية الحامل فإها تستبرأ عند المالكية والحنابلة بثلاث حيضات أو بمضي ثلاثة

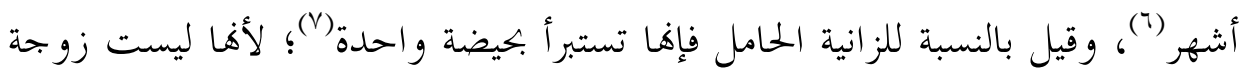

(T) النكاح باطل كالتي تتزوج بغير شهود، ونكاح امر أة الغير بلا علم بأها متزوجة، ونكاح الخارم (ابــن

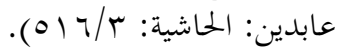

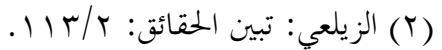

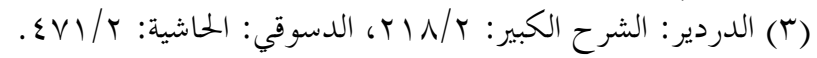

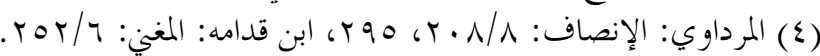

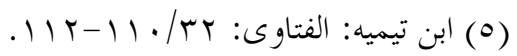

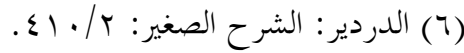

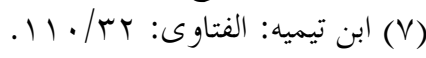


يجب عليها العدة(') ولأنه حرمة للزائ.

واستدل من قال بحرمة العقد على الزانية الحامل أو نكاحها بما يلي:

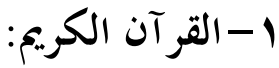

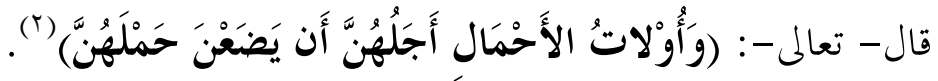

وجه الدلالة: أن المرأة الحامل عليها أن تعتد بوضع الحمل سواء كان الحمل من

نكاح مباح أو من زنا، فالآية عامة تشمل المرأة الحامل من زواج صحيح أو من لمره سفاح

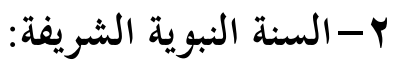

(1) عن سعيد بن المسيب أن رجلاً يقال له نضرة بن أكثم تزوج امرأة فلما

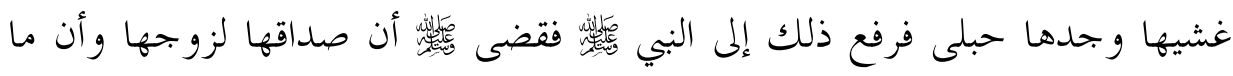

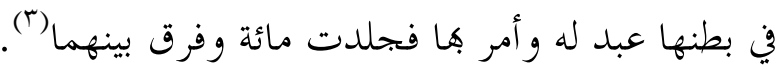

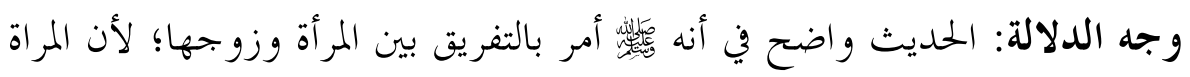
حامل ولا يحل نكاح المرأة الحامل حتى تضع حملها.

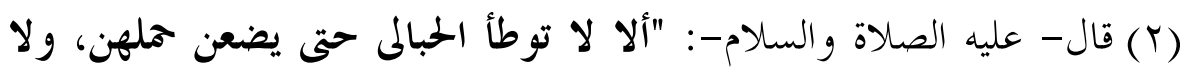

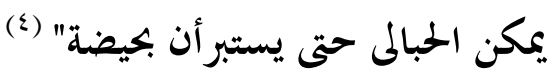

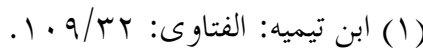

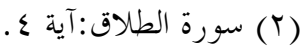

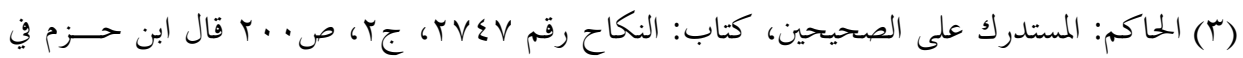

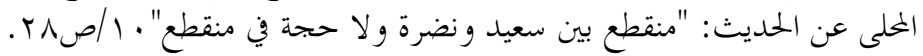

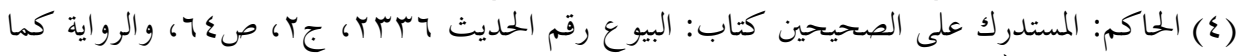

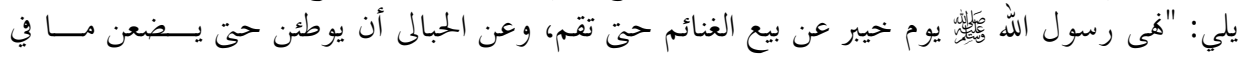

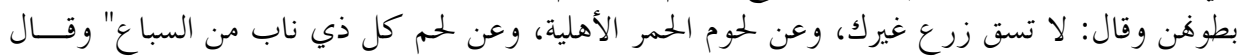

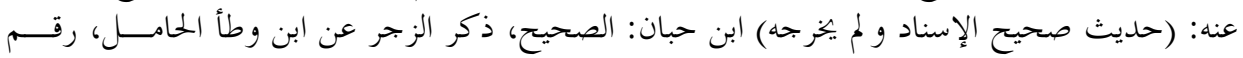


وجه الدلالة: الحديث صريح في عدم جواز وطء الحامل حتى تضع حملها و كلمة

الحبالى عامة تشمل الحمل من الزنا وغيره(').

(广⿳) قال- عليه السلام-: "من كان يؤمن بالله واليوم الآخر فلا يسقين ماءه زرع

غيره" (ن) (r) (ب)

وجه الدلالة: في الحديث وجوب الاستبراء من عدم حمل المرأة عند نكاحها (َ)؛

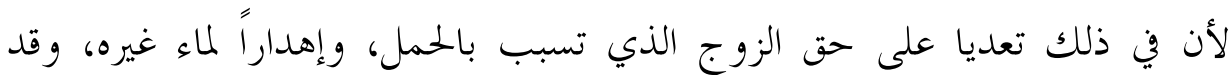

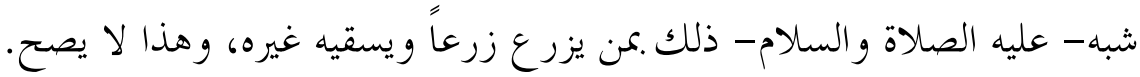

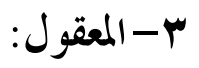

1- صيانة الحمل عن سقيه بماء الغير لا لصاحب الماءع).

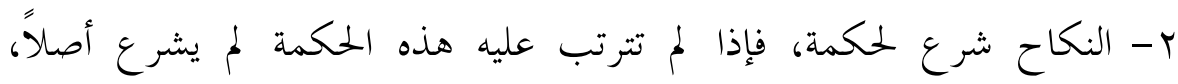
فالأحكام المرتبة من حل الوطءو وجوب النفقة والسكن، بخلاف ما لو تزوجت بالزابي

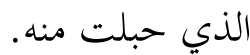

r- القياس، فكما لا يصح العقد على الحامل من غير الزنا لا يصح العقد على

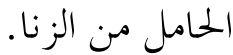
ع - ولأن النكاح له حرمة، و هذه الحرمة تمنع من صب ماء الحلال على الماء

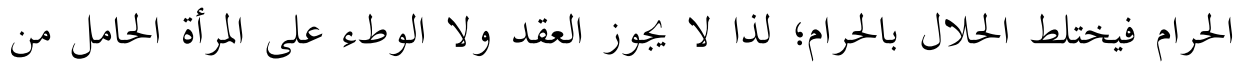
الزنام) (0)

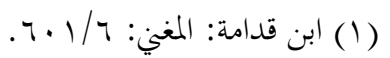

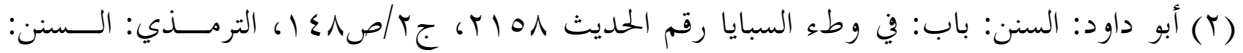

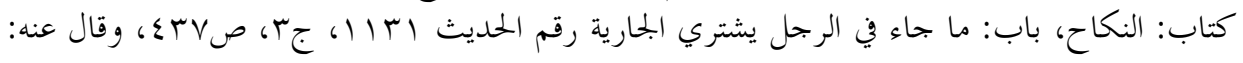




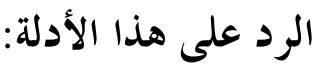

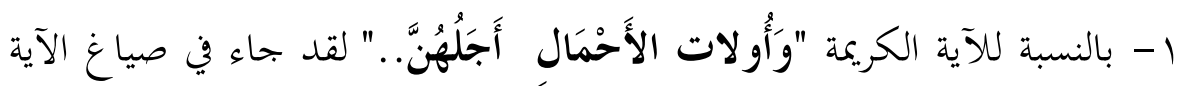

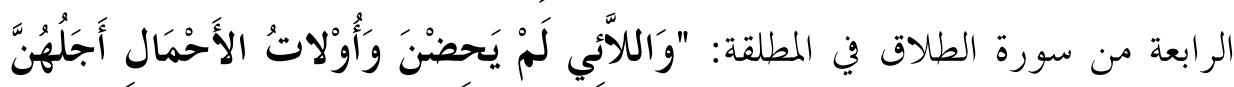

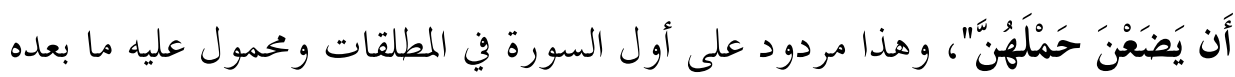

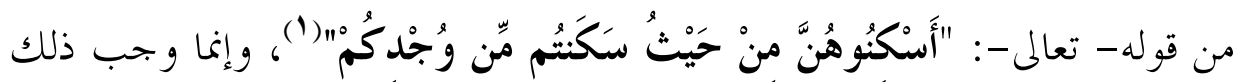

في المتوفى عنها(؟)، وذلك بخبر سبيعة الأسلمية التي وضعت حملها بعد وفاة زوجها. ץ- بالنسبة لحديث سعيد بن المسيب فهو حديث منقطع بين سعيد ونضرة ولا لا

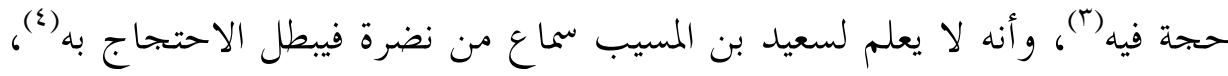

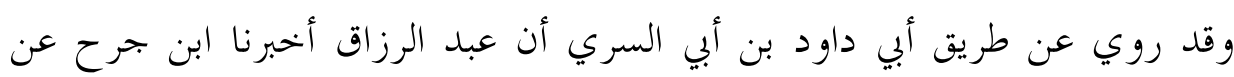

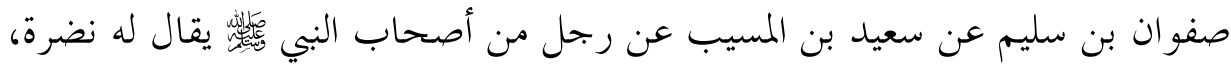

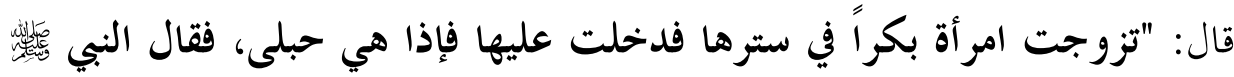

لها الصداق بما استحللت من فرجها و الولد عبد لك وإذا ولدت فأجلدها" (o) وجه الدلالة: "أمر - عليه الصلاة والسلام- بإعطائها الصداق والولد يكون عبداً

للزوج، كما أن عليه أن يقيم حد الجلد، و لم يذكر في الحديث تفريقاً بينهما.

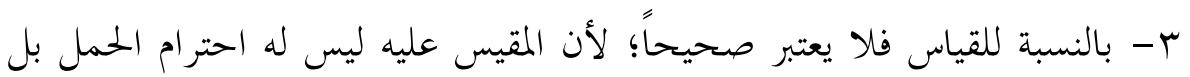

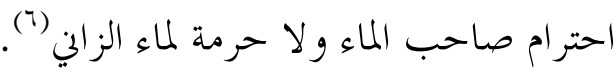

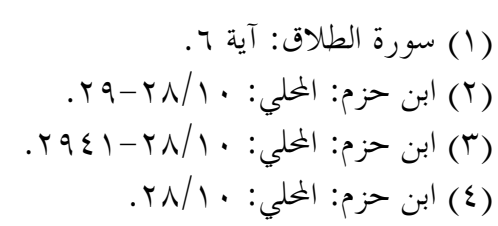

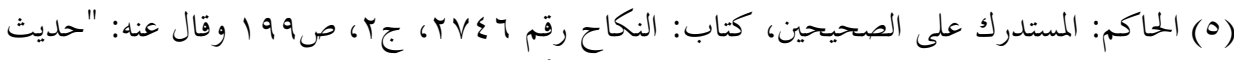

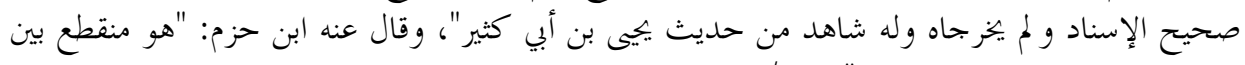

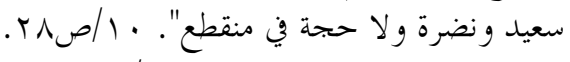

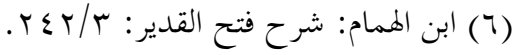




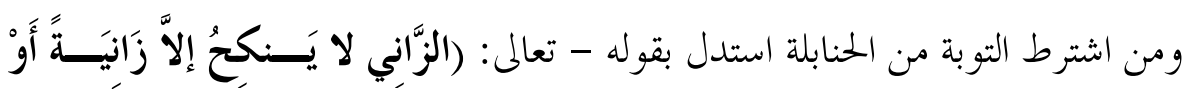

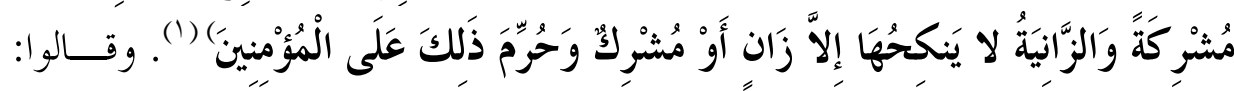
يشترط حسب الآية التوبة(r).

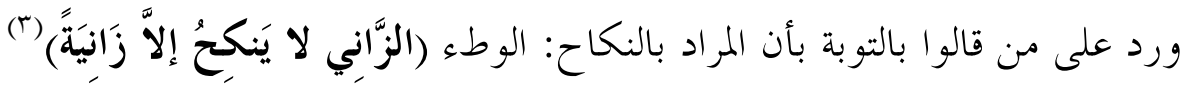

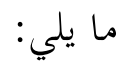

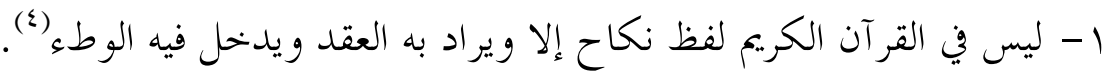

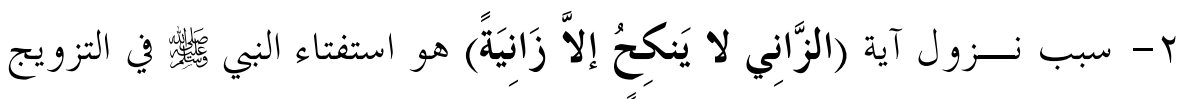

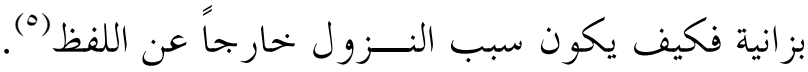

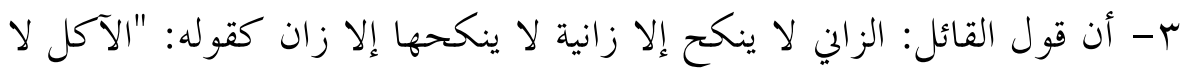

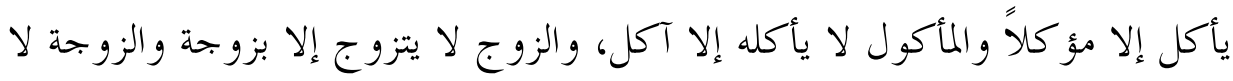

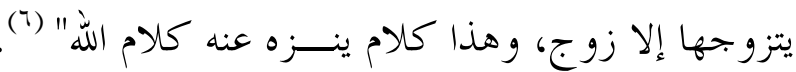

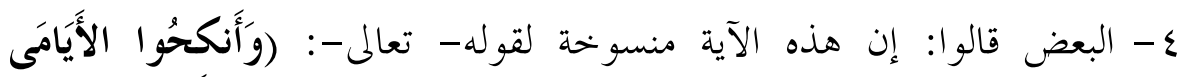

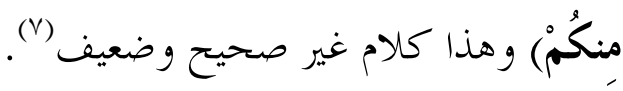
والقول الثاني: يجوز العقد على الزانية الحامل وغير الحامل من الزنامن من غير الز النيا،

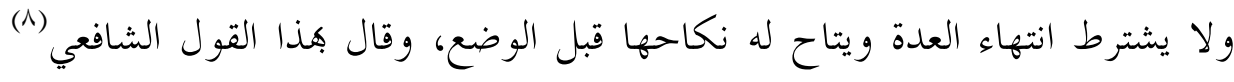

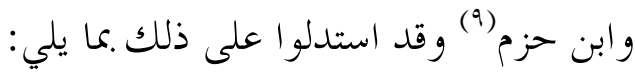

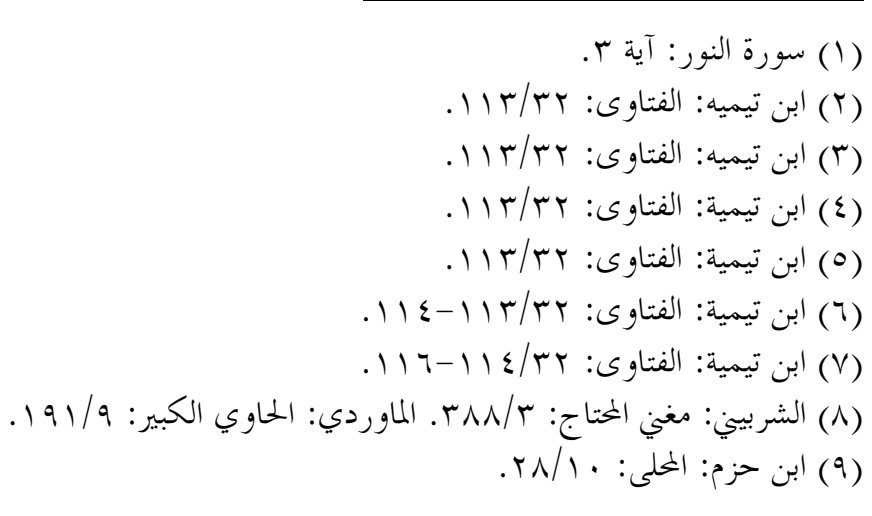




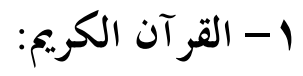

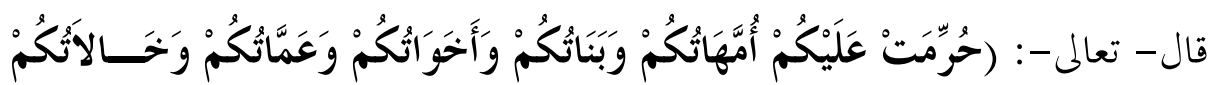

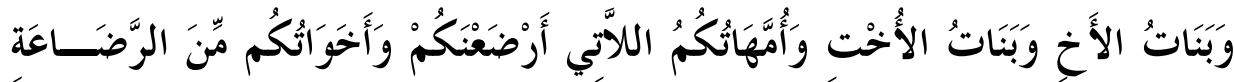

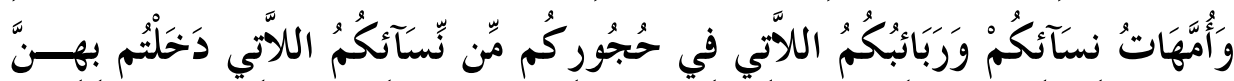

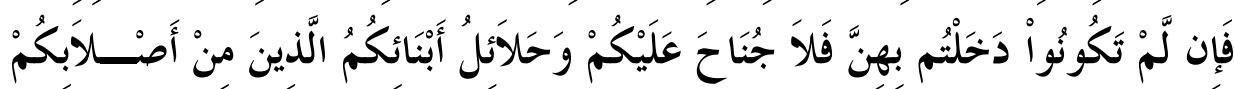

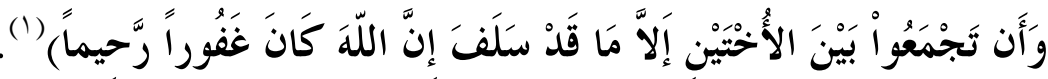
وجه الدلالة: ذكرت الآية السابقة أصناف النساء المحرمات اللواتي لا يحل

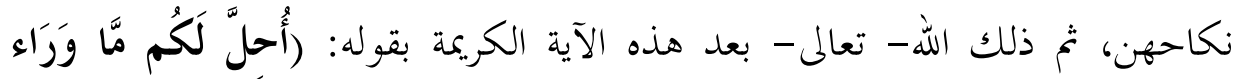
ذَلكُمْ). أي: يباح لكم الزواج من غير هذه الأصناف المذكورة، و المرأة الحامل الزانية ليست من هذه الأصناف؛ لذا يباح نكاحها.

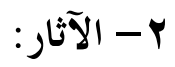

أ- ـ روي عن إسماعيل بن اسحاق أن علي بن عبد الله بن سفيان بن عينية بن عبيد

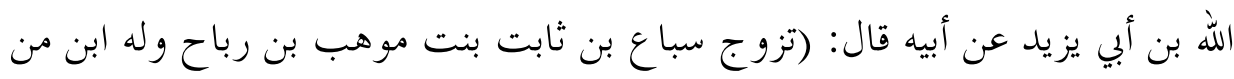
غيرها، ولها بنت من غيره، ففجر الغلام بالجارية فظهر هـا حمل، فسئلت فاعترفت بن بن بن بن فرفع ذلك إلى عمر بن الخطاب فاعترفا فحدها وحرض على أن يجمع بينهما فأبى

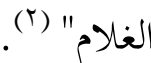

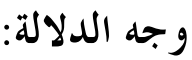
أ- أن عمر بن الخطاب نِّئَّ وهو من كبار الصحابة وقوله معتبر، يبيح للحامل من 
الزنا الزواج، وهذا حدث بحضرة الصحابة ثِيّية ولا يعرف له مخالف (1). ب-إن أبا الزبير قال: (خطبت إلى رجل أخته فذكر أفا كانت أحدثت. يعني: زنت، قال ابن وهب أخبرلي عمرة بن الحارث هذذا الحبر عن أبي الزبير وفيه أن عمر قال له: انكح واسكت) (Г). و يقول ابن حزم: "فهذا عمر أمرها بالنكاح و لم يستثن حتى تتم العدة ولا إن كانت حاملاً (r).

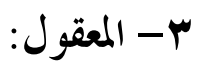

لا حرمة للحمل؛ لذا يجوز نكاح ووطء الحامل من الزنا (ع).

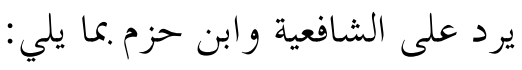

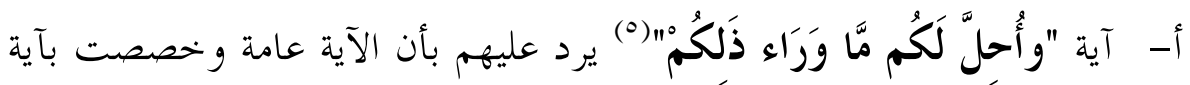

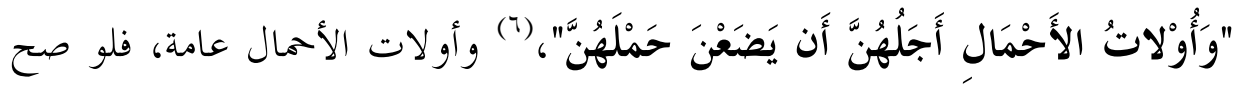
ما قالوه لجاز نكاح الحامل من نكاح شرعي قبل وضعها- وهذا قياس مع الفارق-

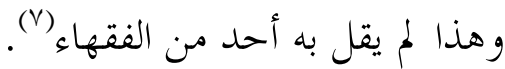

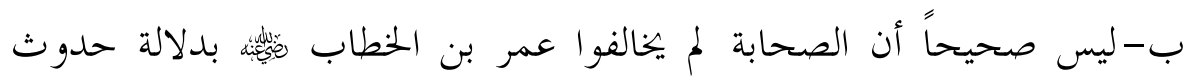

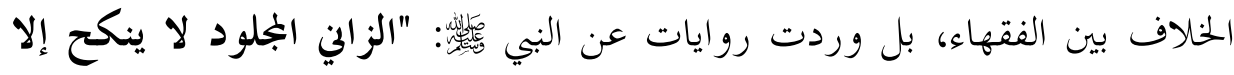
مثله"(^). وفي الحديث دليل على أن لا يحل للرجل أن يتزوج ممن ظهر منها الزنا

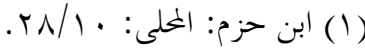

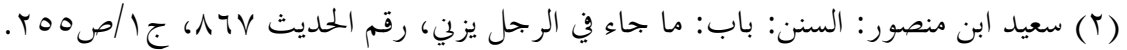

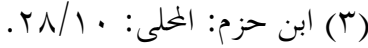

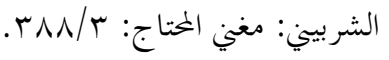

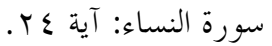

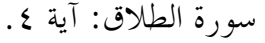

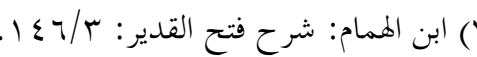

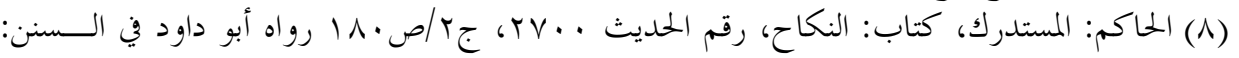

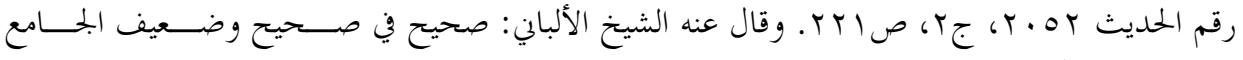

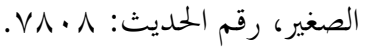




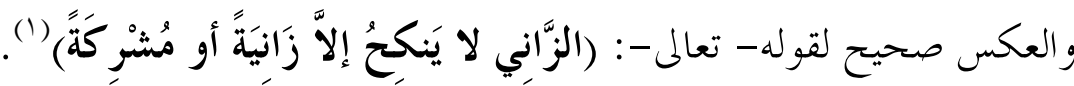
ج- إن العدة و جبت لحق الغير، وخوفاً من اختلاط الأنساب؛ لذا أوجب أن تعتد بوضع الحمل.

القول الثالث: يصح نكاح المرأة الزانية الحامل من الزاني أو من غيره ولا تعتد اتفاقًا عند الحنفية، و إن نكحها الزاني وأتت بولد بعد النكاح لستة أشهر فالولد له وإلا لا يثبت له النسب ولا يرث منه، أما إن كانت المزلي هما حاملاً فيصح العقد عليها، ولكن لا يطؤها حتى تضع عند أبي حنيفة ومحمد بن الحسن وأبي يوسف الأنصاري في أحد أقو الهم (r)

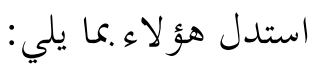

$$
\begin{aligned}
& \text { 1- القر آن الكريم: }
\end{aligned}
$$

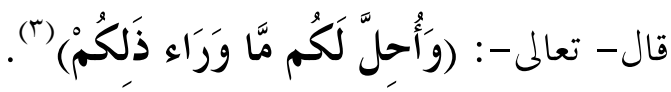

$$
\begin{aligned}
& \text { و جه الدلالة: }
\end{aligned}
$$

أ--لم تذكر الآية المزني بها من المحرمات فيكون مباحا نكاحها ويصح العقد ويمنع

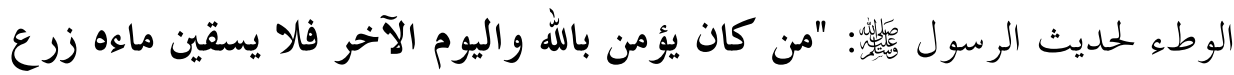
غير ه" (๕) ب- النهي يفيد التحريم؛ لذا يمتنع وطء الحامل كي لا يسقي ماؤه زرع غيره،

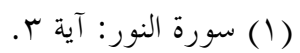

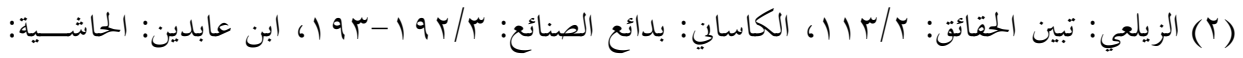

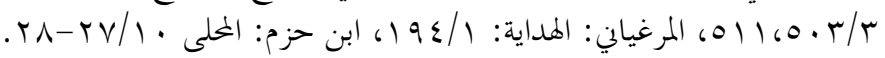

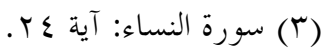

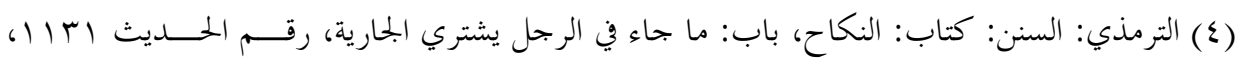

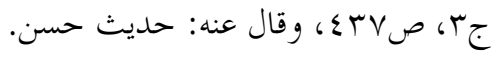


وهذا لا يكون إلا في الحامل، وعليه فلا بجب النفقة لعدم التمكن من الوطء (1).

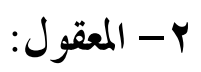

أ- حرمة الوطء هي لعارض يزول بوضع الحمل؛ لذا لا يستلزم فساد النكاح كما في حالة الحيض و النفاس (r). ب- العدة من أجل موت الزوج أو طلاقه و ليس لأجل الحمل من الزنا.

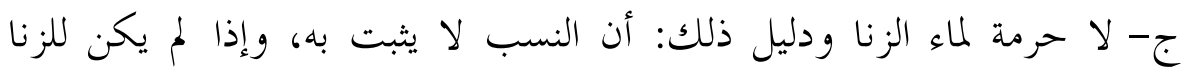
حرمة فإن النكاح لا يمنع.

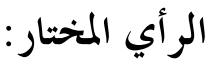

أرى أن نكاح الحامل الزانية محرم حتى تستبرأ من حملها؛ لأن الإسلام يحرص على الأسرة والأنساب، فإن وطء الحامل من الزنا فيه مزج الماء الحلال بالماء الحرام. أي: مزج جرجئ الخبيث بالطيب وهذا لا يصح؛ لذا ينتظر حتى تضع الزانية حملها إن كانت حاملاً ثم بعد والِ

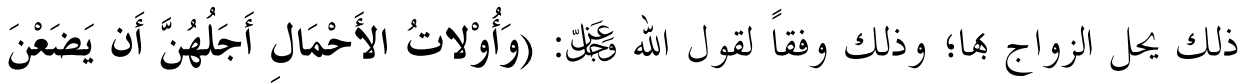
حَمْلَهُنَّ)، فكما هو مبين في الآية السابقة أنه لمُ يتم التفريق بين المرأة الحامل من نكاح صحيح أو من سفاح، وكما أن الأحاديث التي استدل هها أصحاب هذا الرأي تئكد حرمة نكاح المرأة الحامل من الزنا أحاديث صريحة تحرم مثل هذا النكاح، و الله أعلم.

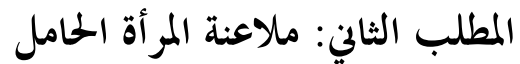
الملاعنة يقصد ها: رمي الزوج لزوجته بالزنا ونفي حملها، وتنفي هي أن الحمل من غير زوجها(r)، و الملاعنة تكون غالباً بسبب نفي الزنا ولو لم تكن المرأة حاملاً، و لم

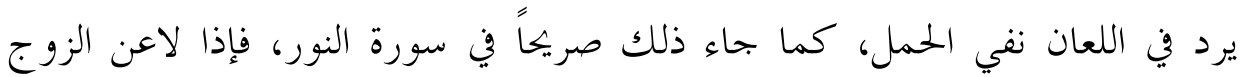
زوجته، فمتت تكون الملاعنة قبل وضع الحمل أو بعد وضع الحمل؟ فحدث الخلاف

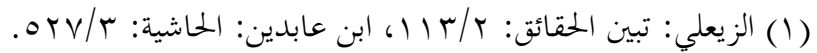

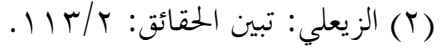

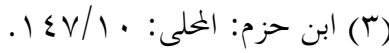


فمتي تكون الملاعنة قبل وضع الحمل أو بعد وضع الحمل؟ فحدث الخلاف بين الفقهاء في هذه المسألة كما يلي:

القول الأول: لا بد من وضع الحمل ثم ملاعنتها، قاله الحنفية(1) وبعض الحنابلة

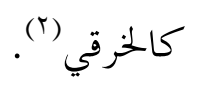

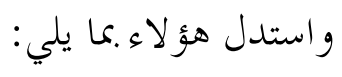

1- الحمل غير مستيقن فقد يكون ريحاً أو غيرها؛ لذا يصير نفي الولد مشروطاً

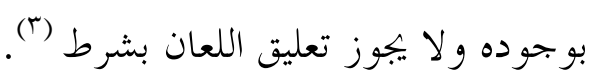

r- لوجود شبهة ولما من الأثر الكبير في الإلحاق بدليل حديث الملاعنة لاعنة. ب- لا يصح استلحاق الولد الملاعن، ولو صح استلحاقه لزمه بترك نفيه كالمولود،

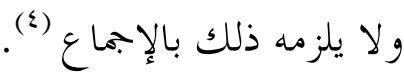
القول الثاني: لا يشترط وضع الحمل حتى تتم الملاعنة، قال ذلك: مالك (0)،

$$
\text { و واستدل هؤلافعي (1)، و الجمهيور. }
$$

- - حديث هلال وأنه نفى حمل زوجته، فنفاه - عليه الصلاة والسلام- عنده وألحقه بالأول، و كان هذا حملاً لقوله هلئل سابغ الأليتين خدلج الساقين فهو لشريك بن سحماء، فجاءت به كذلك، فقال -

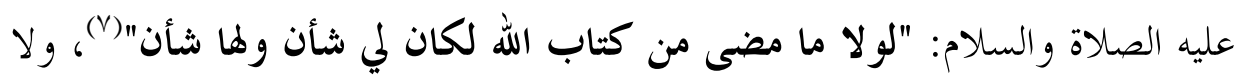

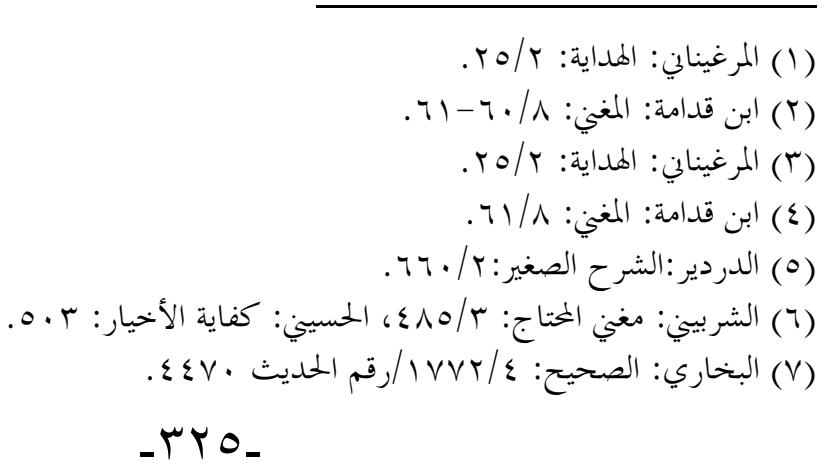




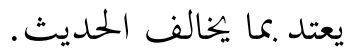
r- لأن الحمل مظنون بأمارات تدل عليه؛ ولهذا ثبت للحامل أحكام تخالف

الحمائل من النفقة والفطر في رمضان ويصح استلحاق الحمل كالولد بعد وضعه (1). r- لأنه محكوم- أي: الأب- بوجوده بدليل وجوب النفقة ووقف الميراث، فصح الإقرار به كالمولود؛ لذا إذا استلحقه لم يملك نفيه بعد ذلك كما لو استلحقه بعد الوضع.

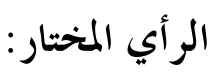
تصح ملاعنة المرأة الحامل، وذلك واضح في حديث هلال عندما لاعن زوجته وهي

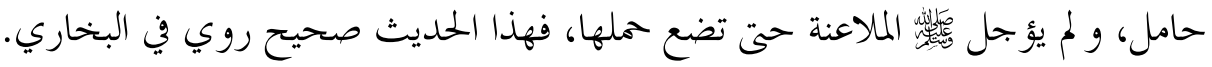
المطلب الثالث: حكم إذن المرأة للطبيب بالإجهاض

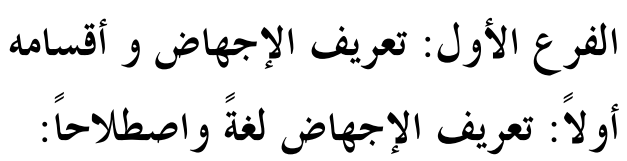
الإجهاض لغه: من أصل جهضة وأجهضت الناقة. أي: أسقطت، والإجهاض هو: الإزلاق، وقيل: خروج الجنين من رحم أمه قبل تمام الشهر الرابع. وأجهضت الحامل. أي: أسقطت وليدها قبل تمام تكو ينه فهي بجهض

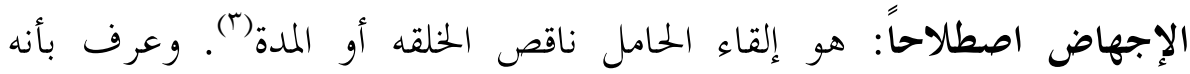

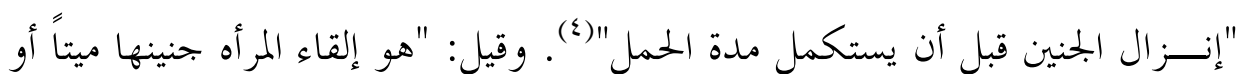

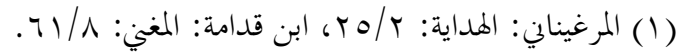

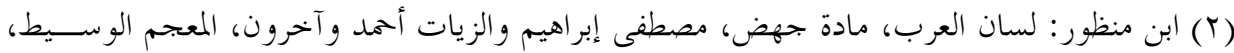

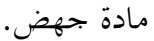

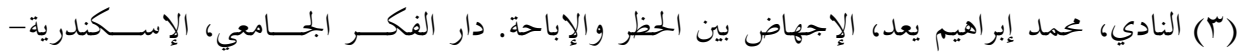

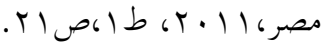

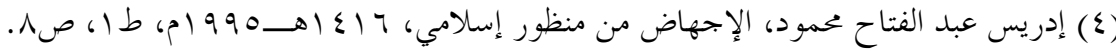


حيا دون أن يعيش، وقد استبان بعض خلقه بفعل منها أو من غيرها "( ). نلاحظ أن التعريف الأخير- وهو المختار- أكثر دقه في وصف الإجهاض ووضع الجنين وقد احتوي على قيود بخلاف التعريف الأول والثاني. فذكر قيد (ميتاً أو حيا دون أن يعيش) يخرج به الحداج، ويشمل الجنين المتوفن في رحم أمه فيجهض عن طريق و سائل طبية وبتدخل الطبيب، ويشمل الجنين الذي يجهـض وهو غير قابل للحياة؛ وذلك لأنه إذا نــزل الجنين قبل الأسبوع العشرين أو كان وزنه . . . جم يعتبر سقطاً أما إذا نــزل بين الأسبوع الرابع والعشرين و السادس والثالثين فيسمي خداجاً وهو باذن الله يستطيع العيش لكن مع عنايه طبيه فائقه (r) . وذكره قيد (بفعل منها أو من غيرها) يشمل ما إذا كان الفعل عمداً أو خطاً سواء من الحامل أو من الطبيب أو غيره. و تستعمل مغردات أخرى مرادفة لإججهاض منها الإسقاط و الإلقاء و الطرح و الإملاص (r). ثانياً: أقسام الإجهاض.

قسم العلماء الإجهاض إلى عدة أقسام وباعتبارات مختلفة، فمنهم من قسمه باعتبار سببه، و منهم من قسمه باعتبار درجته. فالإجهاض باعتبار سببه ينقسم الي قسمين: ا - الإجهاض التلقائي: وهو الذي لا دخل للطبيب أو للحامل في حدوثه، وغالباً ما يكصل نتيجه عدم اكتمال عناصر الحياة للجنين، أو حدوث تشوهات للجنين أو

(1) (1) حمد رحيم، إبراهيم بن محمد قاسم بن حمد رحيم، أحكام الإجهاض في الفقه الإسلامي، إصدارات 
لطبيعة الحالة الجسمية للمرأة أو حصول حادث (1). وهذا القسم خارج موضوع البحث؛ لأنه تلقائي دون إرادة المرأه ولا و جود للإذذن الطبي فيه.

r- الإجهاض الإرادي: "هو الذي يحدث بسبب عامل خارجي من قبل المرأة

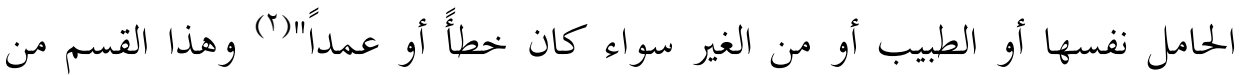
الإجهاض هو المعني بالدراسة، فللمرأة بحال أن تأذن للطبيب بالإقدام علي فعله. وهذا القسم يضم الإجهاض العلاجي وهو الإجهاض الذي يكون فيه تدخل من الطبيب لعلاج ما قد تتعرض له الأم و يتعرض له الجنين من مخاطر أثناء الحمل قد تودي بحياهم معاً أو بحياة أحدهما للخطر، كما يضم الإجهاض الجنائي وهو الذي يتم

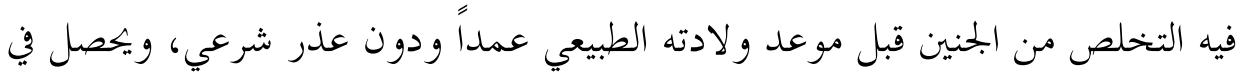

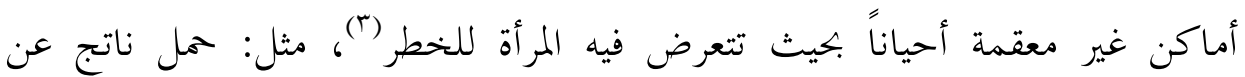

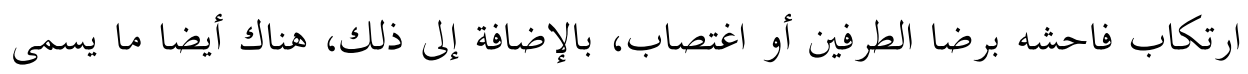
بالإجهاض الجتماعي يندرج تحت هذا القسم، وهو الذي يكون الدافع إلى إجرائه دافع

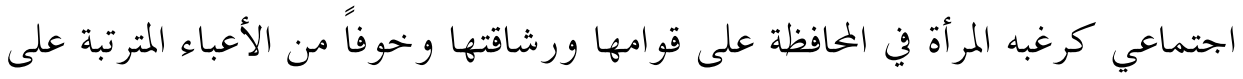
كثرة الأولاد بالإضافه إلى قضية تحديد النسل والجنس (ع). وقسم الإجهاض باعتبار درجته إلى (0):

ا - الإجهاض المنذر: سمي بذلك؛ لنــزول الدم من رحم الحمامل مصاحباً ذلك إلك

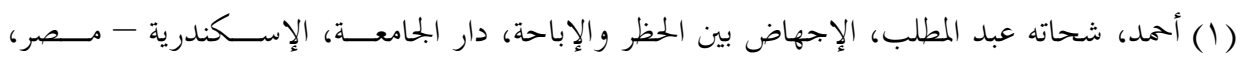

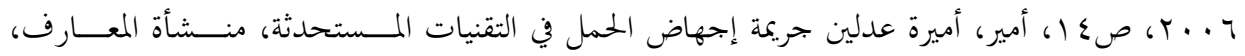

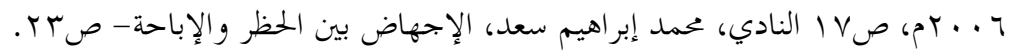

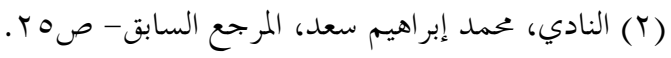

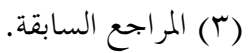
( ) (ع) المراجع السابقة. (ه) أحم، شحاته عبد المطلب حسن- الإجهاض بين الحظر والإباحة، صه 1. 
ب- الإجهاض المحتم: وسمي بذلك؛ لنــزول الجنين من الرحم حتماً مع متويات المجل ب- الإجهاض المختفي: ويحدث داخليا نتيجه نــزيف في الرحم وقد يبقي الجنين داخل الرحم أو يقذف تلقائيا. ع - الإجهاض المتكرر : يتكرر حدوثه لوجود بعض الأمراض. - الإجهاض الجنائي. ج- الإجهاض العلاجي. الفرع الثاني: حكم الإذن بالإجهاض لغير عذر بين الفقه والقانون و يتضمن ثلاثة أقسام: القسم الأول: حكم الإذن بالإجهاض بعد نفخ الروح أولاً: أقوال العلماء في حكم الإجهاض بعد نفخ الروح أجمع الفقهاء على تحريم الإجهاض بعد نفخ الروح على خلاف بينهم في زمن نفخ الروح، حيث ذهب بعضهم إلى أن النفخ يكون بعد مائة و عشرين يوماً وهي تمام الأربعه أشهر قولاً واحداً إلا إذا تعرضت الأم أو الجنين للخطر فيجوز (1) وذهب البعض في رأي آخر إلى أن النفخ يكون بعد الأربعين الأولى، وقد استدلوا جميعهم

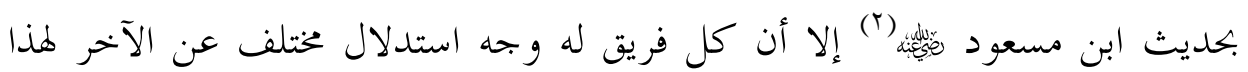

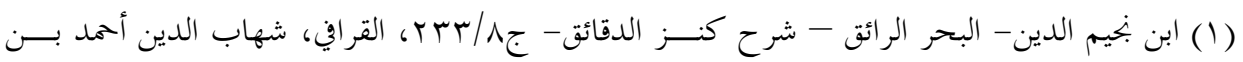

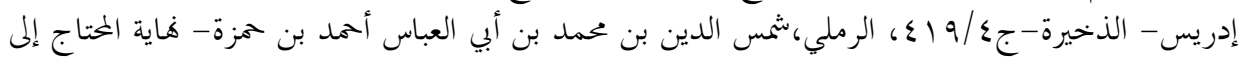

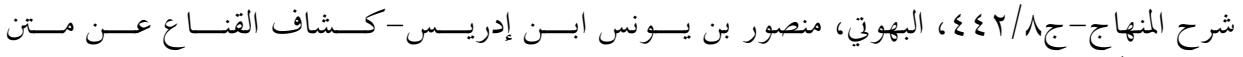

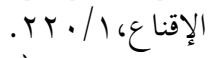

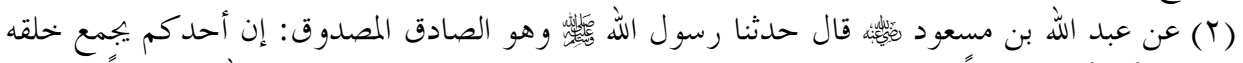

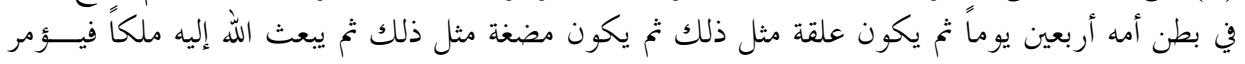

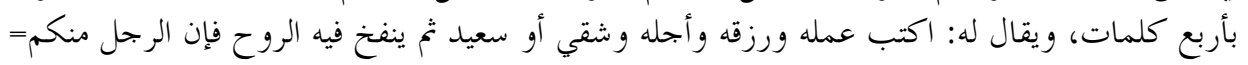


الحديث. فالذين ذهبوا إلى زمن نفخ الروح بعد أربعة أشهر أخذوا بظاهر الحديث،

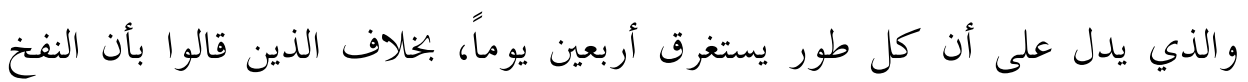

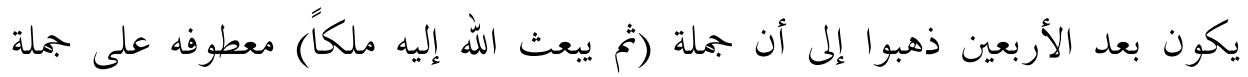

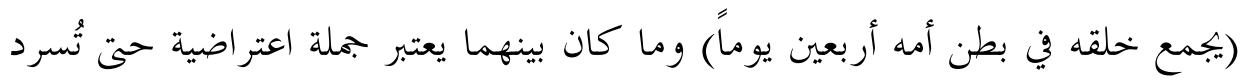
أطوار الجنين مسلسلة دون انقطاع، وقد ورد مثل ذلك في القرآن والحديث وكلام العرب و بالتالي فهو جائز (1) إلا أن بحلس هيئه كبار العلماء في دورته التاسعه والعشرون المنعقدة في الرياض

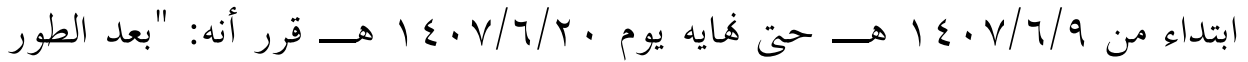
الثالث وبعد إكمال أربعه أشهر للحمل لا يمل إسقاطه حتى يقرر جمع من الأطباء

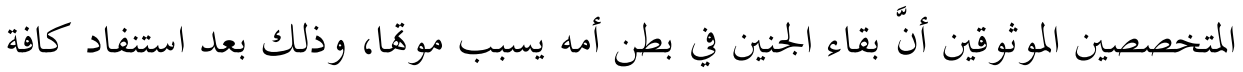

$$
\text { الوسائل لإنقاذ حياها (r) }
$$

استدل الفقهاء على حرمة إجهاض الجنين بأدله هي كالتالي:

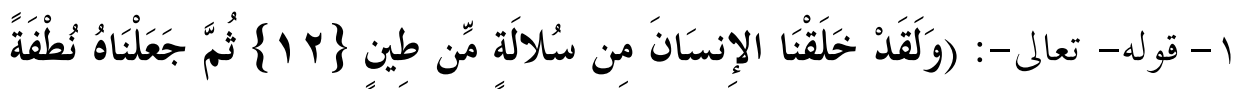

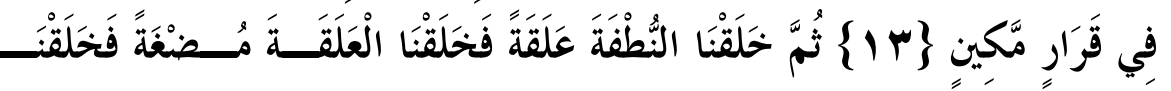

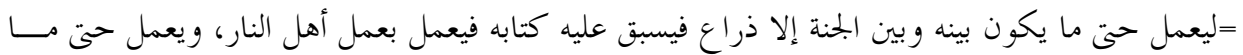

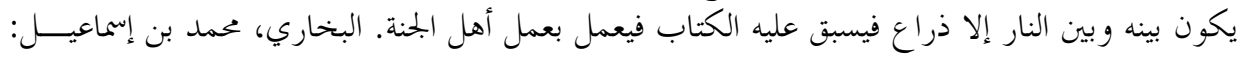

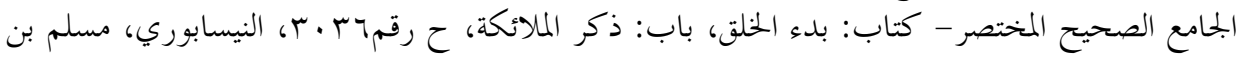

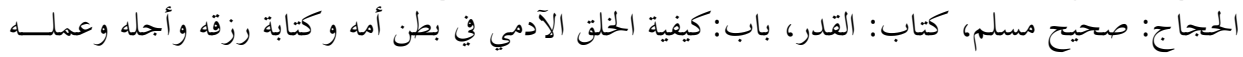

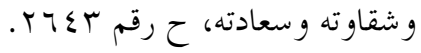

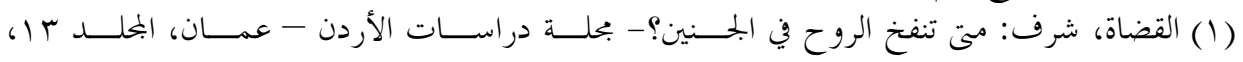

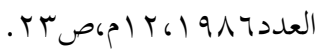

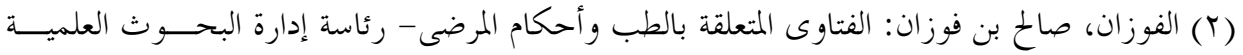

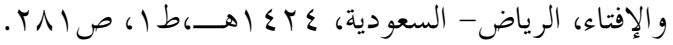

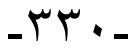




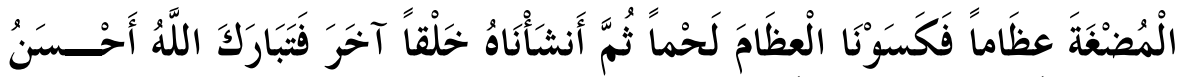

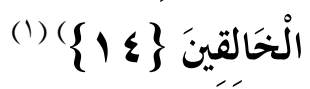

وجه الدلالة من الآيه: وضحت الآية الكريمة مراحل خلق الانسان من النطفه إلى نفخ الروح، والنفخ يكون بعد التصوير والخلق، حيث ذكر المفسرون أن قوله- تعالى-:

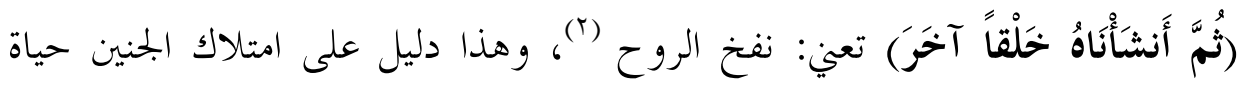

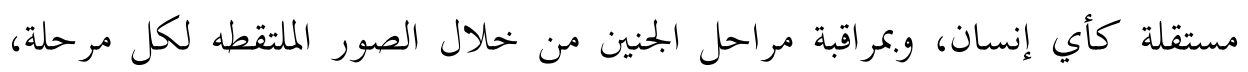
لاحظ الأطباء أنه في المراحل الأولية لا فرق بين جنين الإنسان والحيوان إلا أنه في الأسبوع السابع والثامن يبرز شكله الإنساني المميز وهي معنى قوله- تعالى-: (ثُمَّم

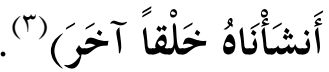

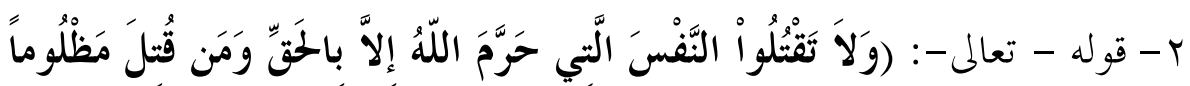

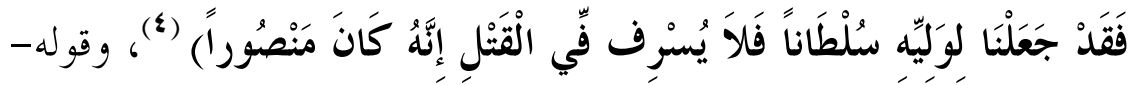

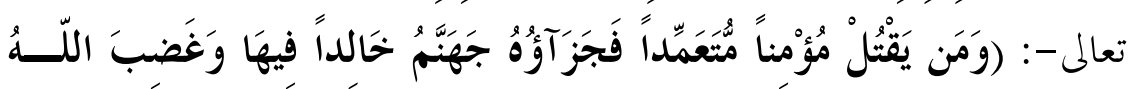

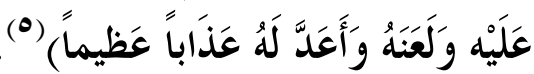

وجه الدلالة من الآيات: بينت الآيتان الكريمتان حرمه قتل النفس بأي وجه وأي

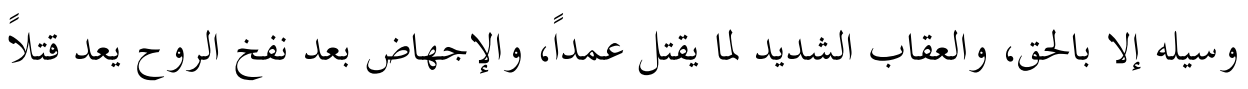
للنفس دون أي حق، فيشمله عموم النهي الوارد في الآيه.

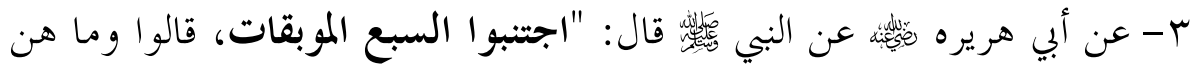
يا رسول الله قال: الشرك بالله، والسحر، والقتل النفس التي حرم الله إلا 
بالحق، وأكل الربا، وأكل مال اليتيم، والثولي يوم الزحف، قذف الخصنات

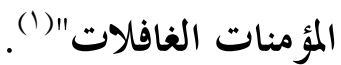

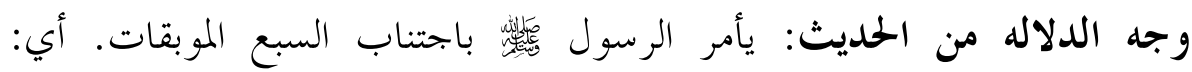

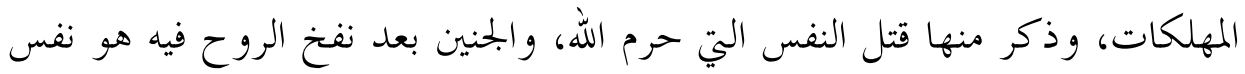
حية يحرم قتلها.

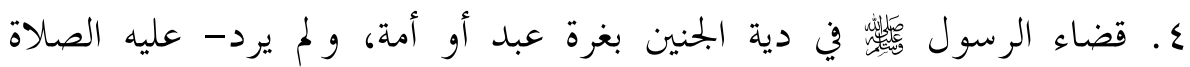

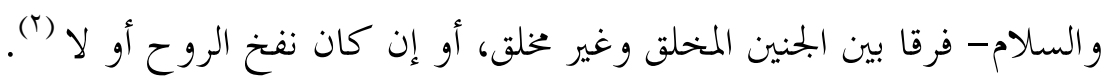

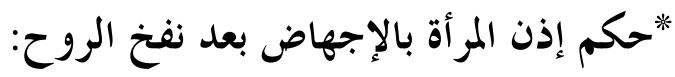

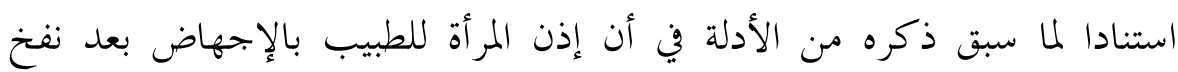

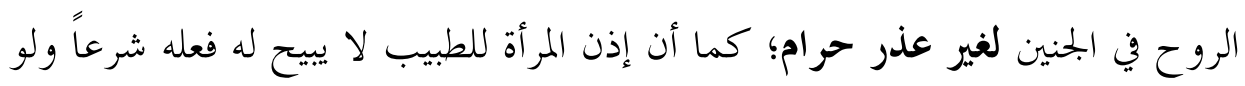

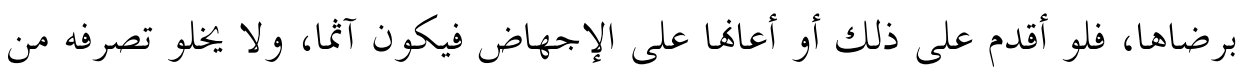

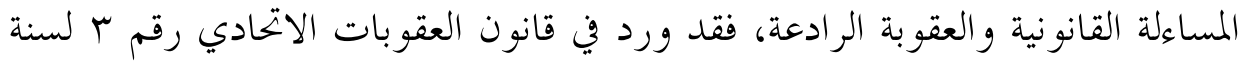

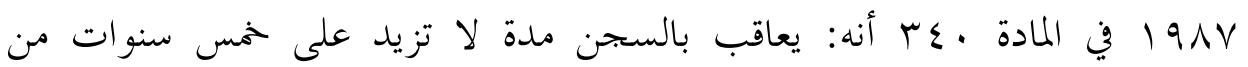

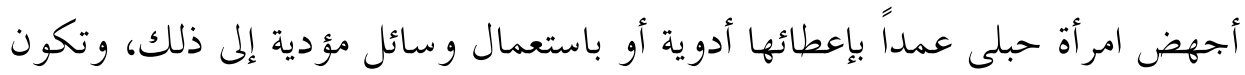
العقوبة السجن مدة لا تزيد على سبع سنوات إذا وقعت الجريمه بغير رضائها.

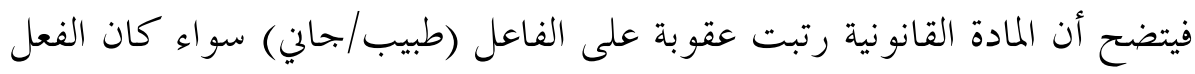

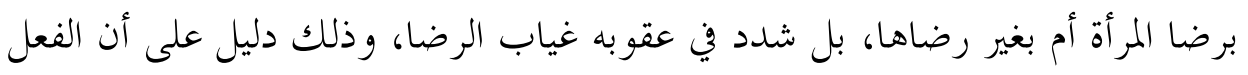

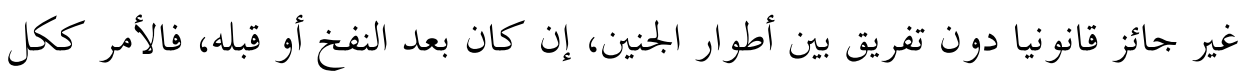

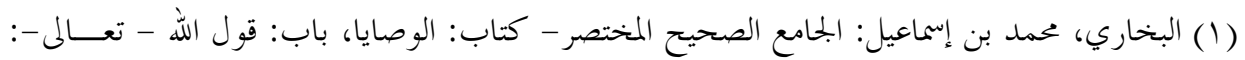

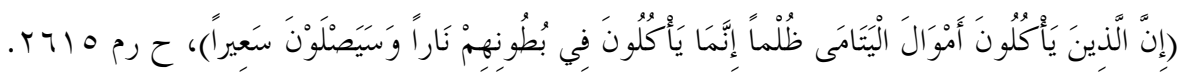

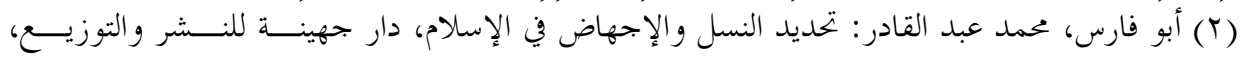
. 111-11. 
مرفوض من قبل القانون ولو تخلله إذن من الحامل.

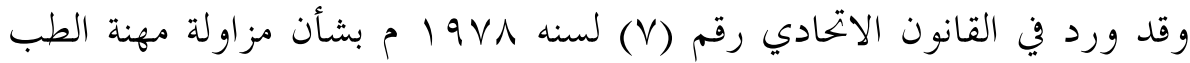
البشري مادة (Yq) أنه: يعاقب بالحبس مدة لا تزيد على أربع سنوات كل طبيب

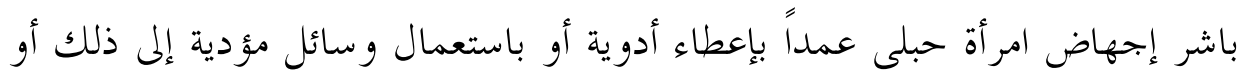
بإرشادها إليها سواء كان الإجهاض برضائها أم بغيره، فإذا أفضى الإجهاض إلى موت

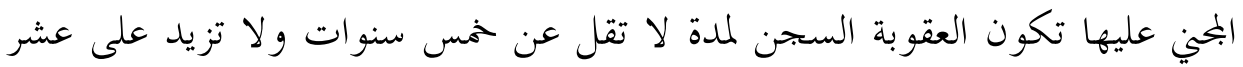
سنوات. وفي جميع الأحوال تحكم المحكمة بمصادرة ما في عيادة الطبيب من أدوات وآلات ومواد تتعلق بمزاولة المهنة وتغلق العيادة مدة مساوية لمدة العقوبة الملكوم هها، ولا يخل ما تقدم بكق اللجنة المنصوص عليها في المادة الرابعة من هذا القانون في سحب الترخيص الممنوح للطبيب بمزاولة المهنة وشطب اسمه من سجل الأطباء.

\section{القسم الثاني: حكم الإذن بالإجهاض قبل نفخ الروح}

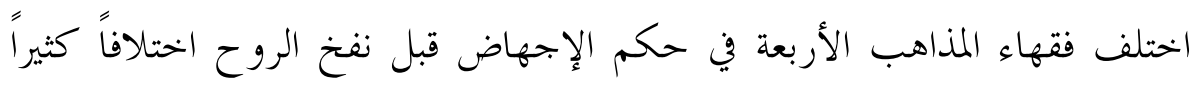
فيما بينهم، على النحو التالي: القول الأول: ذهب الحنفية والشافعية والحنابلة، واللخمي من المالكية إلى إباحة الإجهاض مالم يتخلق الجنين. أي: قبل نفخ الروح، إلا أن الحنابلة قيدو إباحته بالمرحلة الأولى فقط. أي: قبل الأربعين الأولى، ولعل رأي الحنابلة في تخصيص الإباحة قبل الأربعين تو افق مع توصل له الأستاذ شرف القضاة والطب الحديث في أن الروح تنفخ

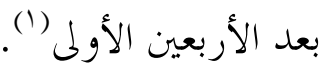

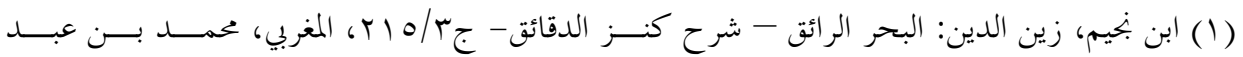

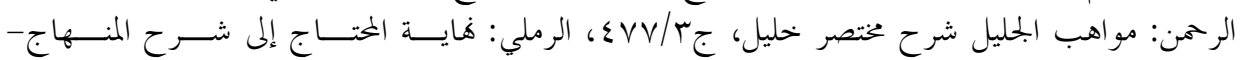

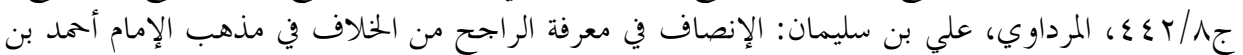

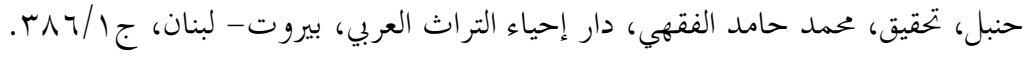


لكن على الرغم من جوازه فإن الحنفية والمالكية و الشافعية كرهروا تنــزيله (1). القول الثاني: ذهب المالكية، وبعض الحنفية، والغزالي من الشافعية، وابن الجوزي

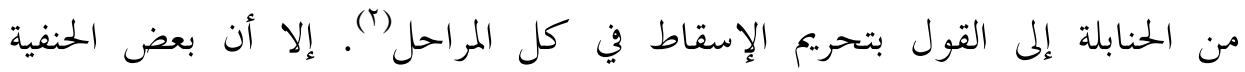

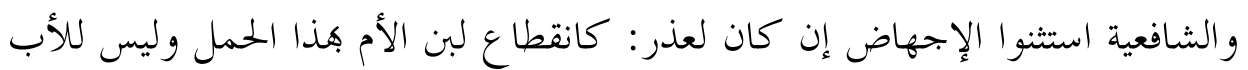
ما يملك ليستأجر مرضعة ترضعه (ب)

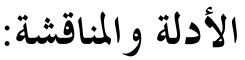
استدل أصحاب القول الأول القائلين بالجواز مع الكراهة بأدلة هي:

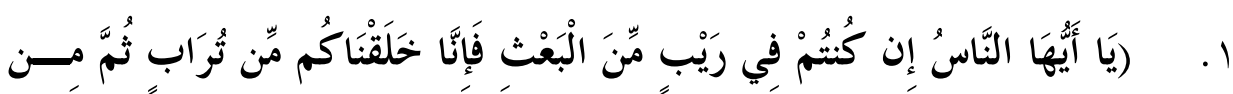

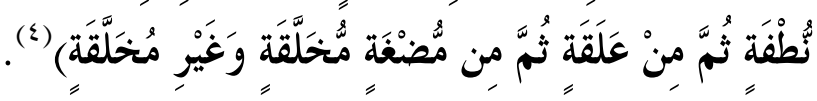
وجه الدلالة: أن الآية الكريمة تدل على أن المضغة قطعة من اللحم لا تشكيل فيها

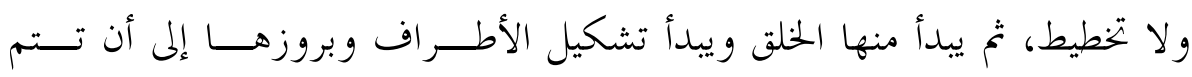

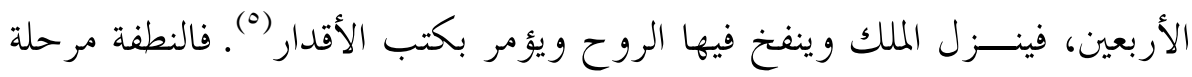

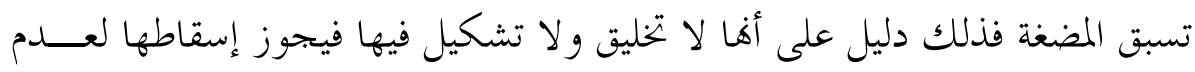
اعتبار آدميتها.

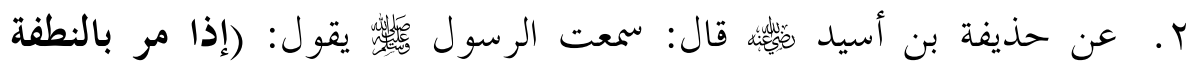
اثنتان وأربعون ليلة بعث الله إليها ملكاً فصورها وخلق سئ سمعها وبصرها

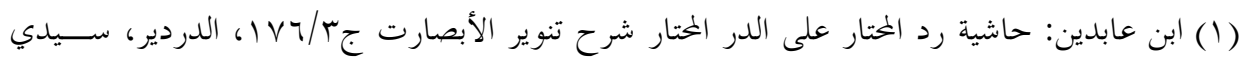

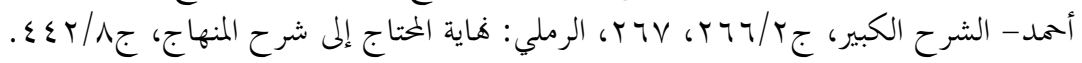

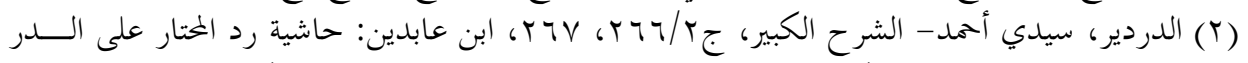

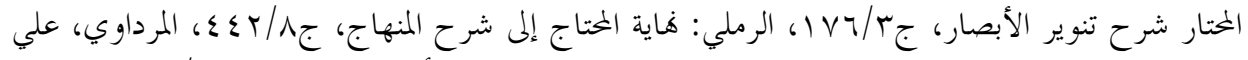

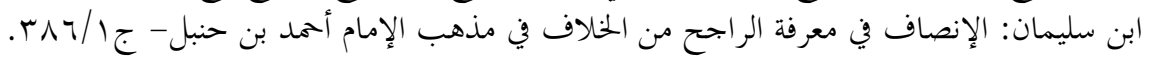

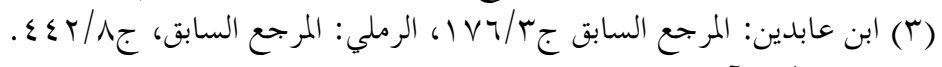

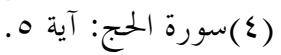
(0) الدمشقي، إسماعيل بن عمر بن كثير: تفسير القرآن العظيم- دار الفكر، بيروت - لبنان، ا. ــ اهـــ tr. 


\section{و وجلدها و لحمها وعظامها...)(')}

وجه الدلالة من الحديث: أن في الحديث بياناً لمرحلة النطفة أن لا تخليق فيها؛ لذاما وحها

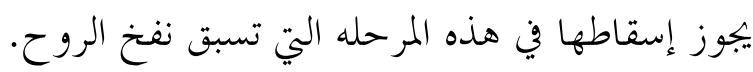

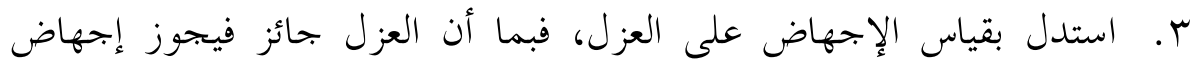

$$
\text { الجنين قبل نفخ الروح. }
$$

وقد رد على ذلك: بوجود فارق بينهما فالعزل لا وجود للولد أصلاً، أما في

$$
\text { الإجهاض فقد عقد وتم تكو ينه فيعتبر اعتداء (r). }
$$

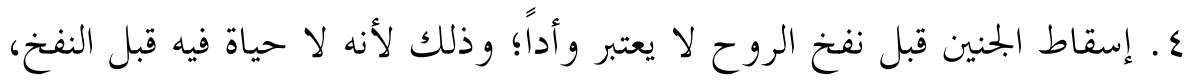

والوأد يقع علي بدن حي وهذا غير متحقق في السقط قبل النفخ فيجوز إجهاضه (r).

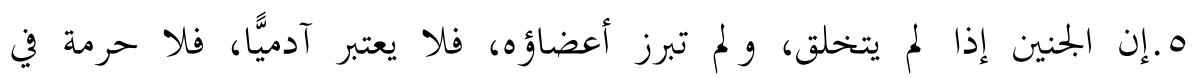

(ع) إجهاضه (1)

استدل أصحاب القول الثاني القائلين بالتحريم بأدلة هي على النحو التالي:

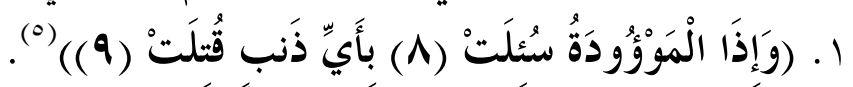

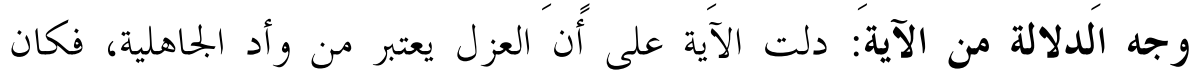
إطلاقه على الإجهاض من باب أولى، ومما يؤكد ذلك ما ذكر في السنة من حديث

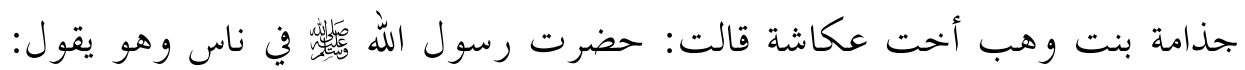
لقد هممت أن أهىى عن الغيلة، فنظرت في الروم وفارس فإذا هم يغيلون أولادهم و لا

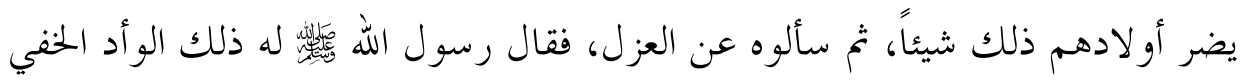

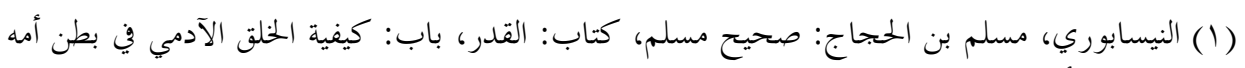

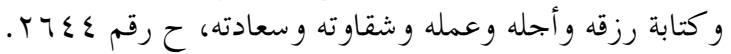

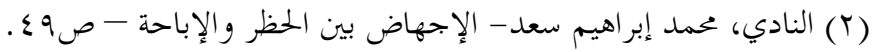

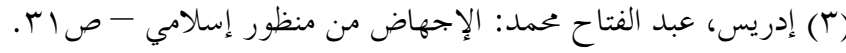

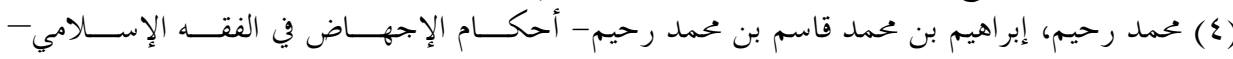




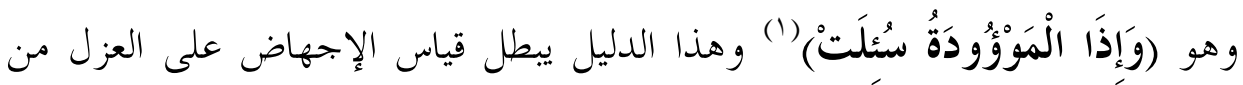
جهة الجواز الذي استند إليه أصحاب القول الأول، كما يبطل استدلالهم من المعقول على نفي صفة الوأد عن الإجهاض لانعدام الحياة قبل نفخ الروح. r. الأدلة من القرآن والسنة التي تنهى عن قتل النفس، فالإجهاض في مرحلة ما قبل النفخ الروح يعتبر قتلاً؛ لأن الجنين له أن ينمو ويهيى بحفظ وعناية الله (r) و وبإسقاطه فيه

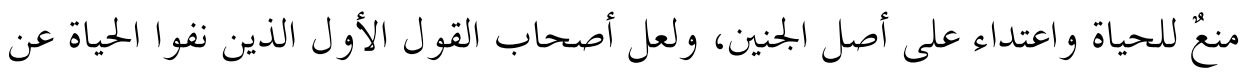
الجنين، قصدوا بذلك الحياة الظاهرة التي تحس هها الحامل، فهم يتفقون على الحياة مادته والدليل حدوث الاتصال بالبويضة (r)، وقد ذكر ذلك الأستاذ علي المحمدي في كتابه حيث قال "والحاصل: أنه بعد نفخ الروح تتحقق إنسانيته مع أنه يتصف بالحياه قبل ذلك (๕)

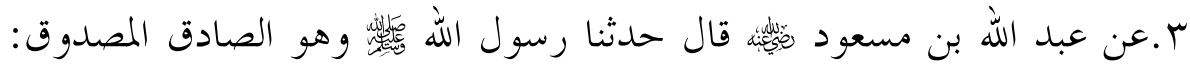
"إن أحدكم يجمع خلقه في بطن أمه أربعين يوماً ثم يكون علقة مثل ذلك، ثم يبعث الله ملكاً فيؤمر بأربع كلمات، ويقال له: اكتب عمله و رزقه و أجله، وشقي أو سعيد، ثم ينفخ فيه الروح، فإن الرجل منكم ليعمل حتى ما يكون بينه وبين الجنة إلا ذراع، فيسبق عليه كتابه فيعمل بعمل أهل النار، ويعمل حتى ما يكون بينه وبين النار إلا ذراع، فيسبق عليه الكتاب فيعمل بعمل أهل الجنة". وجه الدلالة في الحديث: أن خلق الإنسان يُّمع في رحم الأم ويضم لبعضه بعد

(1) النيسابوري، مسلم بن الحمجاج: صحيح مسلم - كتاب: النكاح، باب: جواز الغيلــة وهـــ وطء

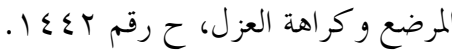

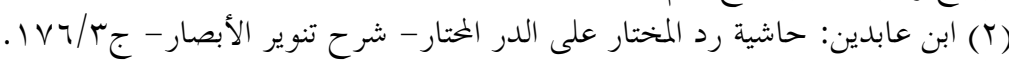

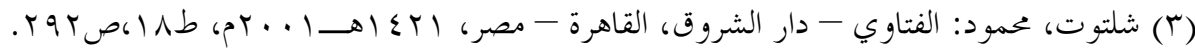

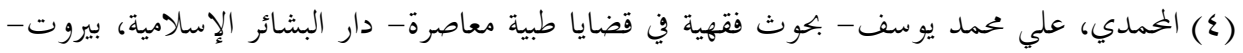

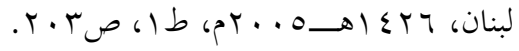

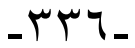


انتشاره في جسدها وذلك في أربعين يوماً كما ورد في مطلع الحديث، وقد وردت روايات كثيرة تؤكد أن جمع المني يكون ابتداءً من الأربعين الأولى (1)، و اتفق الأطباء على أن الخلق والتصوير يكون في نهو الأربعين حيث يكون خفيا ثم يبدأ بالظهور

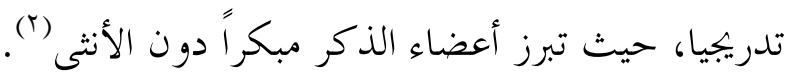
وفي هذا الاستدلال رد وإبطال لأدلة الفريق الأول الذين استدلو ا هـا على أن مرحلة النطفة تبقى على حالها و لا تغيير ولا تخليق فيها.

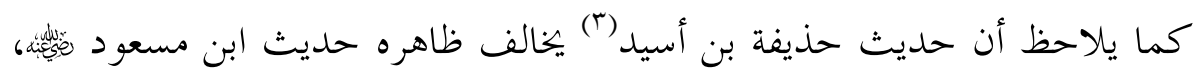
حيث يبين الأول: أن تصوير الجنين وخلق عظمه ولحمه لا يكون غلا في الأربعين

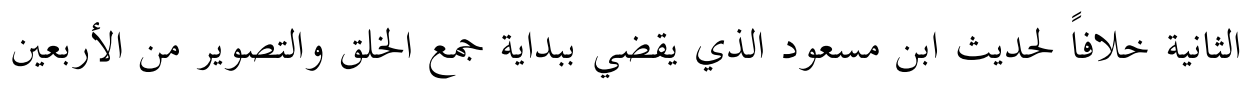

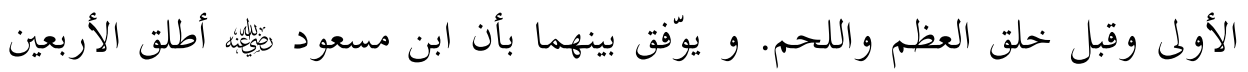
فاحتمل أن يكون الجمع و التصوير في فاية الأربعين الأولى وابتداء الثانية، ويحتمل أن ولن اختلاف ذلك يعتمد على الأجنة (๕).

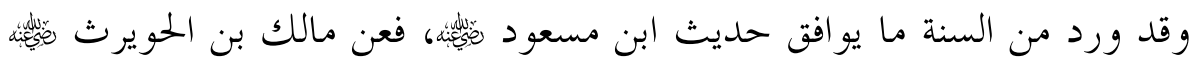

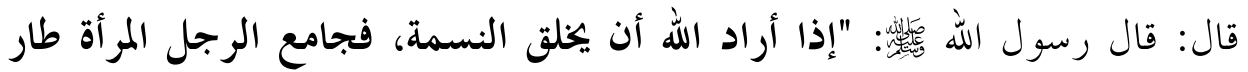
ماؤه في كل عرق وعصب منها، فإذا كان يوم السابع أحضر الله كل عرق بينه

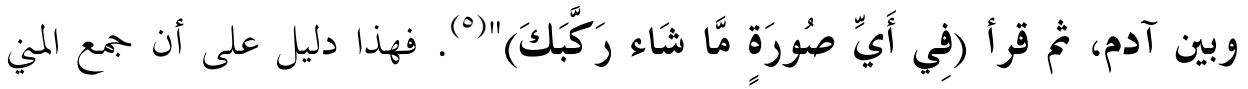

$$
\begin{aligned}
& \text { (1) منها حديث مالك بن حويرث سيأتي ذكره. }
\end{aligned}
$$

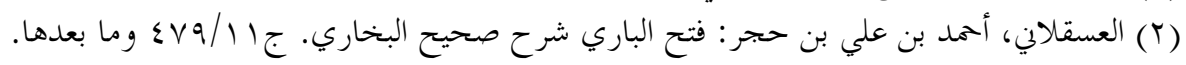

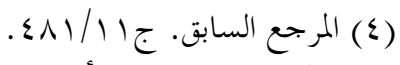

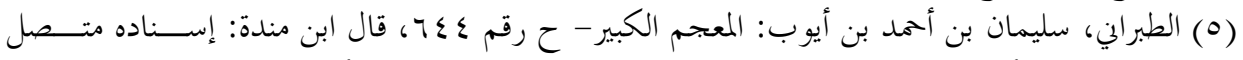

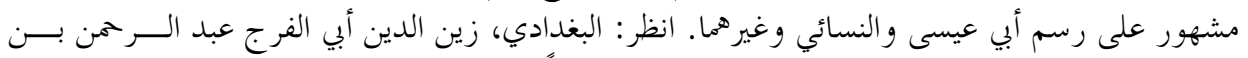

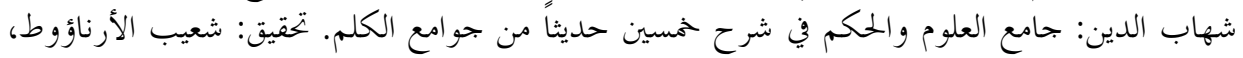

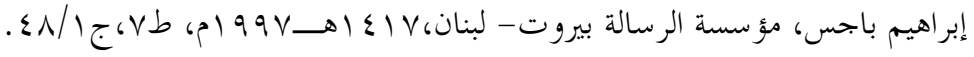




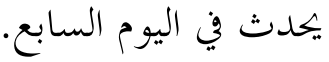

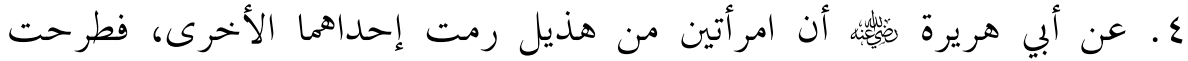

جنينها، فقضى رسول الله وجه الدلالة: كلمة الجمين جاءت مطلقة في الحديث و لم تختص بمرحلة من مراحل فله الحمل، وقد رتب الرسول لَّل على إسقاط الجنين عقوبة حيث قضى بينهما بالغرة دون

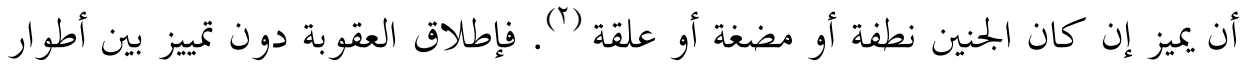
الجنين وترتيب الإثم لدليل على حرمة هذا الفعل في أي مرحلة من مراحل الحمل.

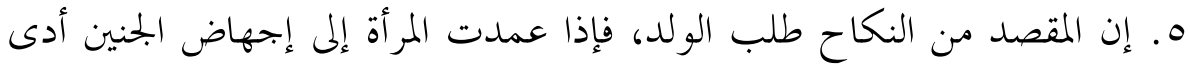
فعلها إلى مخالفة مقاصد الشريعة (").

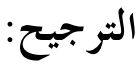

إن حلاصة ما ذهب إليه الفريقان هو وجود فرق بين مرحلة الجنين قبل نفخ الروح

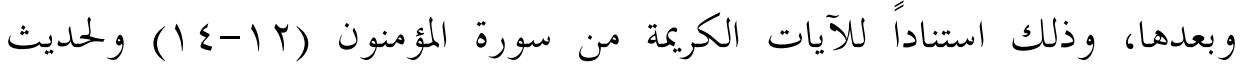
الرسول لَّل الذي يبين أطوار الجنين، فذهب أصحاب القول الأول إلى جواز الإجهاض

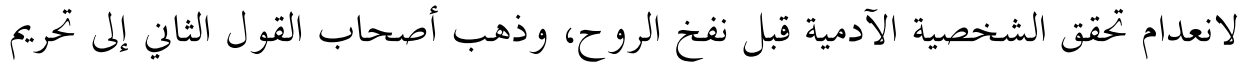
هذا الفعل وتجريمه لو جود الحياة النباتية من نمو وتشكيل للجنين مآلها للحياة.

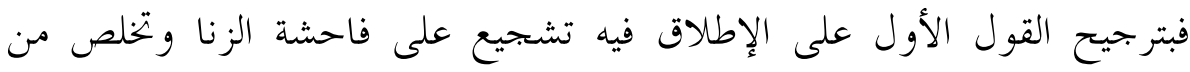

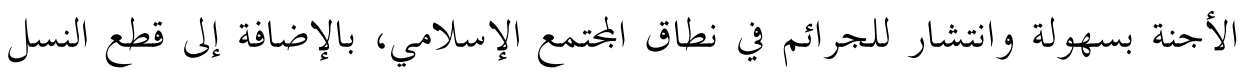

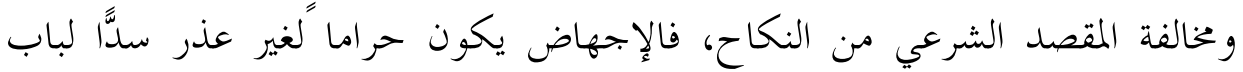

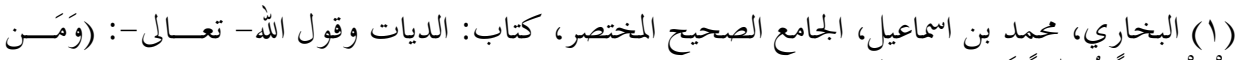

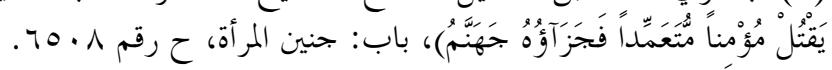

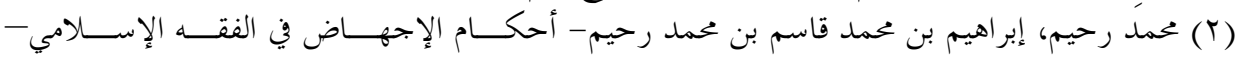
(r) أممد شحاته عبد المطلب حسن: الإجهاض بين الحظر والإباحة صrه. 
الذريعة على الجمتمع الإسلامي وتزداد الحرمة بازدياد قرب فترة النفخ وهو الأصل إلا أن للضرورة أحكامها وقواعدها، فيباح الإجهاض لعذر تقرر اللجنة الطبية خطورته التي تصل إلى درجة الضرورة، حيث تطبق عليه القواعد الخاصة بالضرورة، لا سيما إن

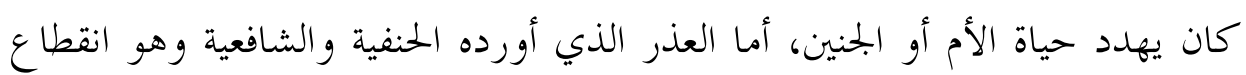

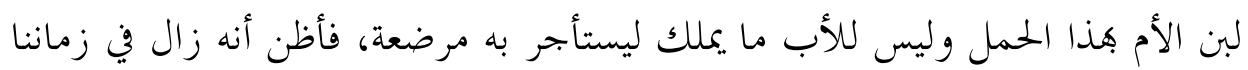
بتوفر الحليب الصناعي ولا يعتبر عذراً يبيح الإجهاض، و الله أعلم.

\section{*حكم المرأة بالإجهاض قبل نفخ الروح:}

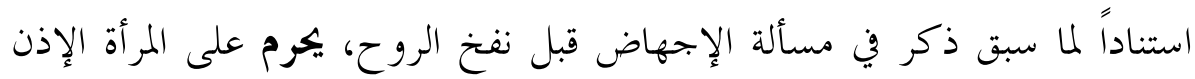

للطبيب بإجهاض الجنين قبل نفخ الروح لغير عذر، و كذلك بالنسبة للطبيب، فإذذن

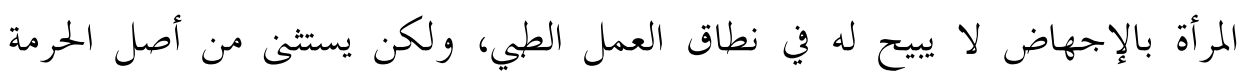

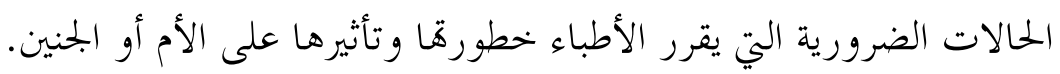

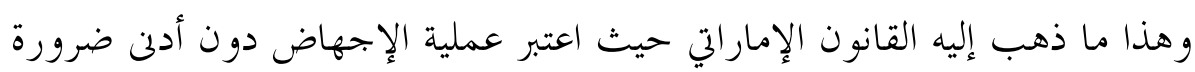

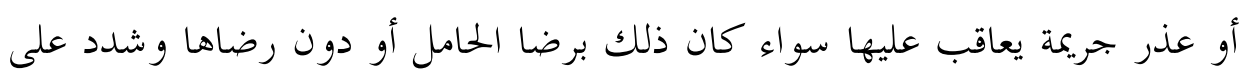

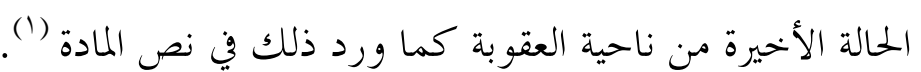

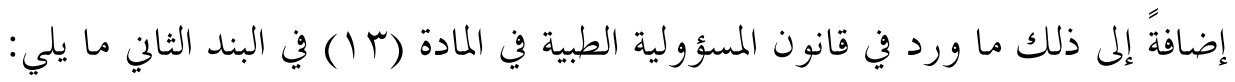
ثانياً: لا يجوز للطبيب أن يجري أية عملية إجهاض أو أن يصف أي شيء من شأنه إجهاض امرأة إلا في الحالتين التاليتين:

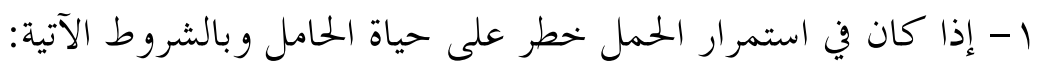

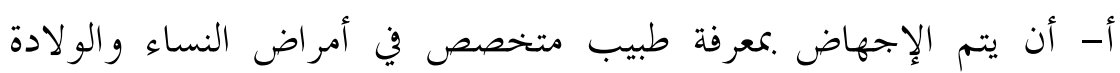

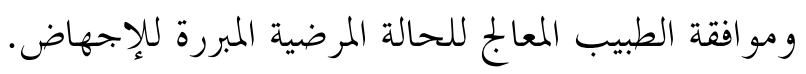

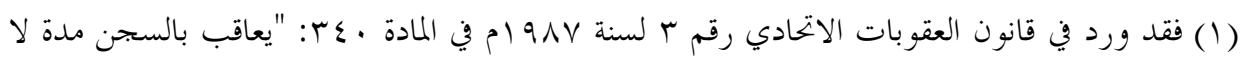

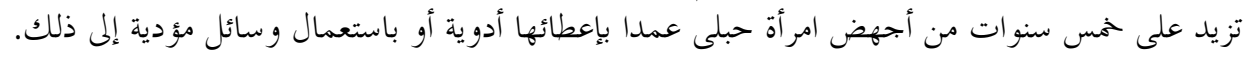

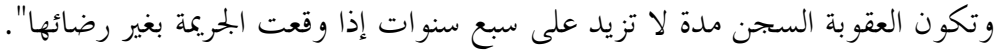


ب- أن يحرر محضر بتقرير السبب المبرر للإجهاض .معرفة الأطباء المعنيين على

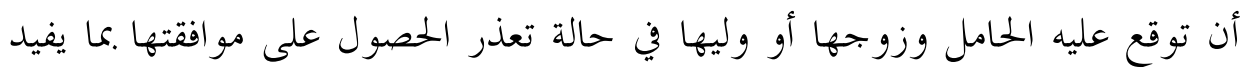

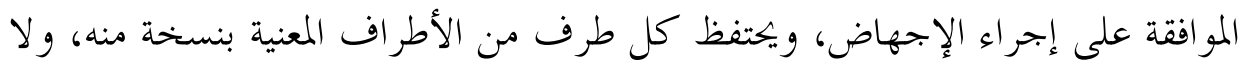
تشترط موافقة الزوج في الحالات الطارئة التي تتطلب تدخلاً جر احيًّا. r - إذا ثبت تشوه الجنين و بالشروط الآتية: أ- أن يكون الإجهاض بناء على طلب الو الدين. ب- ألا يكون قد مر على الحمل مائة وعشرون يوماً. ت- أن يثبت التشوه بتقرير لجنة طبية تضم استشاريين في تخصص أمراض النساء و الولادة والأطفال والأشعة. ث - أن يكون تقرير اللجنة مبنَّا على الفحوص الطبية واستخدام التقنيات المتعارف عليها علميًا. ج - أن يكون الجنين مشوهاً تشوهاً خطيرًا غير قابل للعلاج بحيث يؤدي إن ولد حيَّا إلى أن تكون حياته سيئة و آلاماً عليه وعلى أهله. القسم الثالث: أثر دو افع الإجهاض على الإذن به إله أولاً: أثر الدافع الجنائي إن التحلل الأخلاقي وضعف الوازع الديني وما يبث في الإعلام الهابط من سموم تشوش الفكر، تعد من الأسباب المساهمة في انتشار فاحشة الزنا في البحتمع الإسلامي

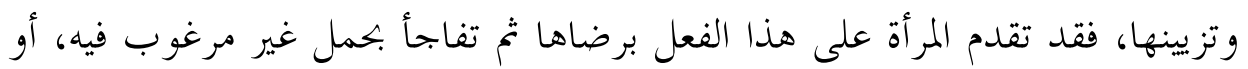

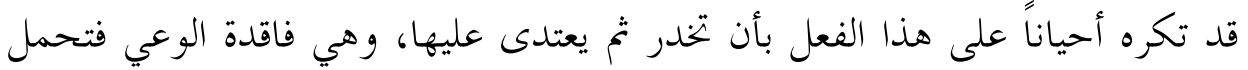

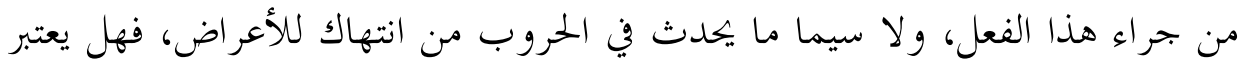
دافع التستر على الفاحشة ذا أثر قبيح للمرأة الإذن بالإجهاض؟ أو هل يفرق بين المكرهة وغير المكرهة فيباح للمكرة بحجة أن لا يد لها في الأمر؟ 
إن أذن المرأة للطبيب بإجهاض الحمل الناتج عن زنا بإتفاق الطرفين يطبق حكم الإذن بالإجهاض لغير عذر وهو التحريم ولا أثر للدافع على حكم الإذن الطبي فيه سواء كان الجنين في مرحلة ما قبل نفخ الروح أم بعدها، وذلك للأسباب والأدلة

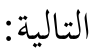

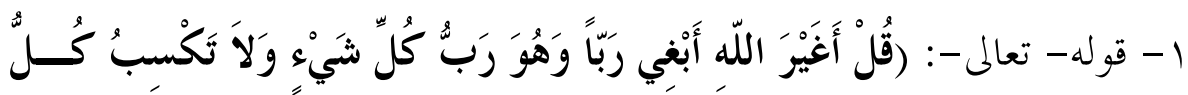

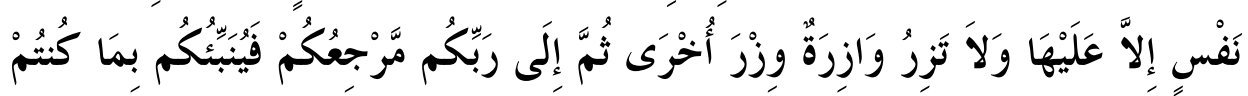

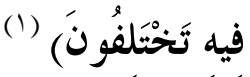
وجه الدلالة من الآية: يقول الطبري في تفسير هذه الآية: "ولا تأثم نفس آثمة بإثم

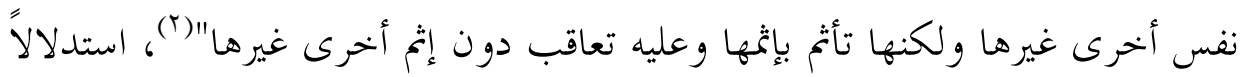
بذلك لا يجوز أن يجهض الجنين نتيجة فعل لا ذنب له فيه ولا دخل فلا يعاقب بجرم غيره، بل الجاني هو من يعاقب ويتحمل نتيجة فعله.

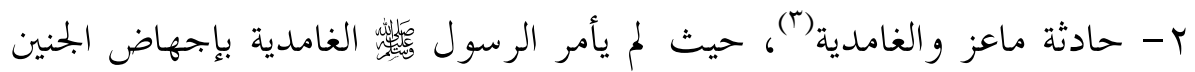
الناتج عن الزنا، بل ردها حتى تضع حملها ثم ردها ثانية حتى ترضعه، ويستقل بحياته

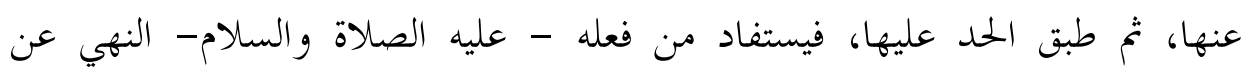
الإجهاض في مثل هذه الحالة، بل أوضح فعله - عليه الصلاة والسلام-- مدى اعتناء

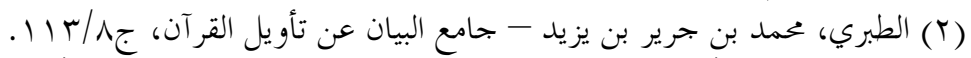

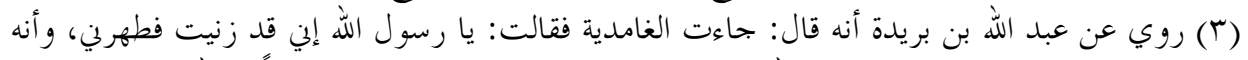

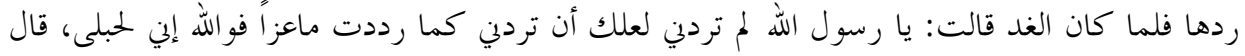

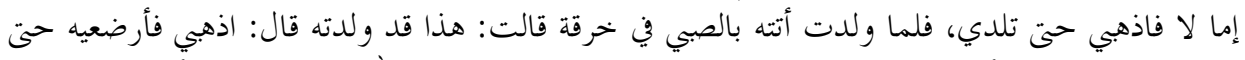

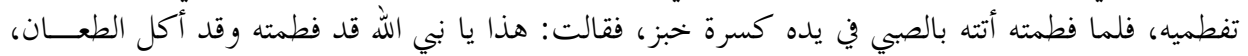

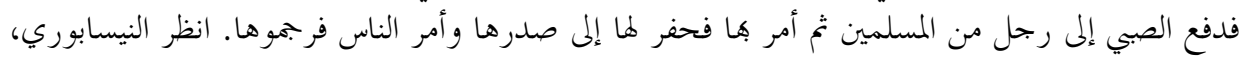

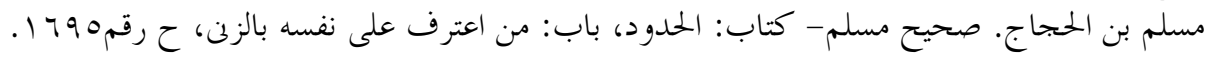




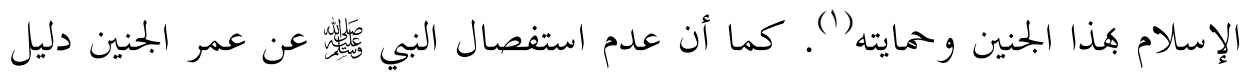
على أن الحرمة تسري على جميع مراحل نمو الجنين. r- عدم شرعية الدافع شرعاً وقضاء، فإن القول بالجواز يزيد من انتشار فاحشة الزنا و لا يحدها.

ع - أما بالنسبة للمكرهة على الزنا، فالأصل أن يبقى حكم الإذن بالإجهاض بعد

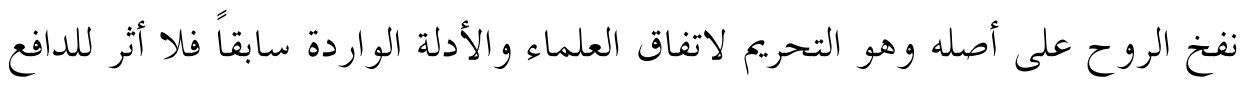
على ذلك، أما إن كان الجنين في مرحلة ما قبل الأربعين فيمكن أن يكون للدافع أثر على حكم الإذن، فينتقل من التحريم إلى الجواز لعذر الإكراه وذلك للأسباب التالية: 1- إجازة الحنابلة الإجهاض قبل الأربعين الأولى كما أجاز بعض فقهاء الحنفية والشافعية كما تقدم قبل نفخ الروح لعذر انقطاع لبن الأم عن الرضيع، وفي هذه

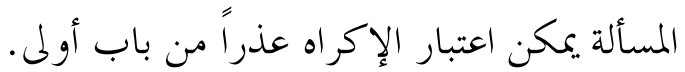

r- الضرر النفسي المترتب على المرأة من جراء هذا الفعل، والشعور بالحرج من ولادة طفل دون أب شرعي، فدفعاً لذلك يمكن الأخذ برأي الفقهاء الذين أجازوا ذلك قبل أن يتخلق الجنين فيكون نفساً حية (r). ثانياً: أثر الدافع الاجتماعي

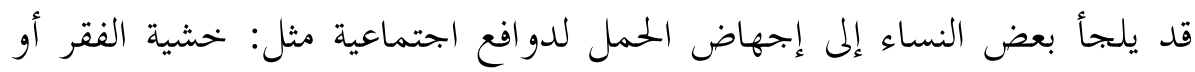

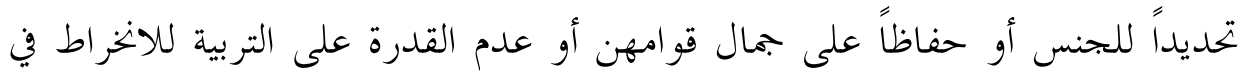

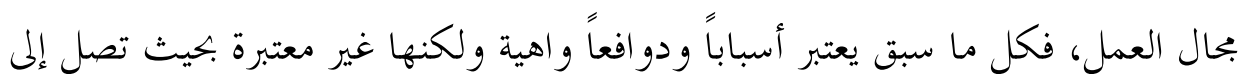

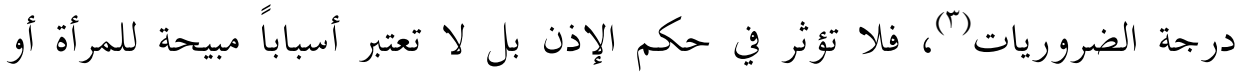

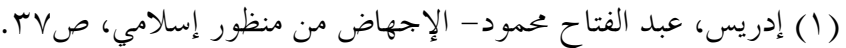

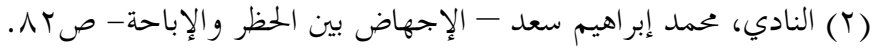

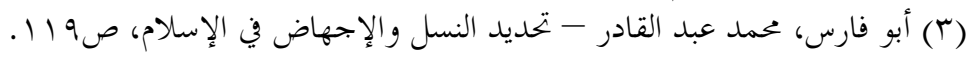


للطبيب الإقدام على إجراء عملية الإجهاض.

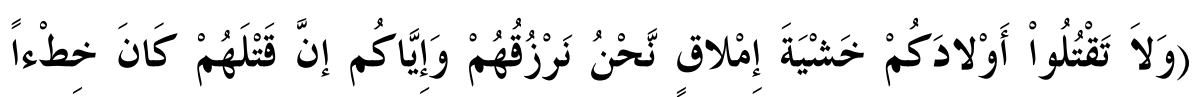

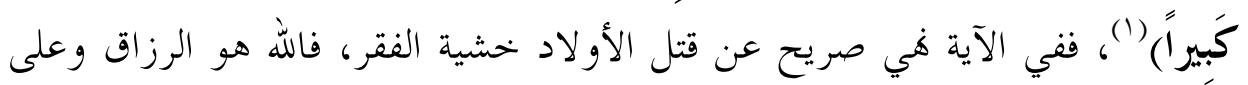

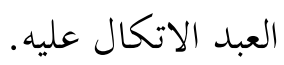
وقد أفتت اللجنة الدائمة للبحوث العملية والإفتاء في المملكة الفتوى رقم

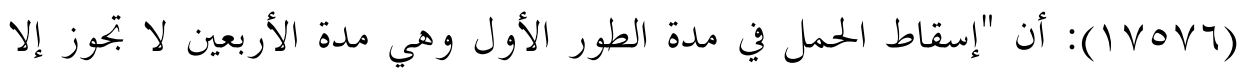

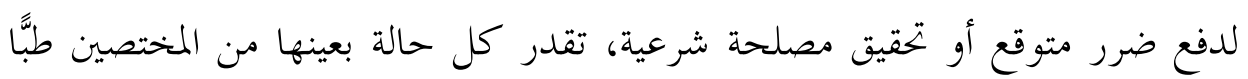

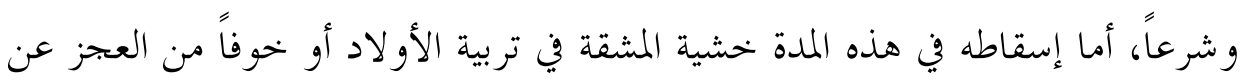

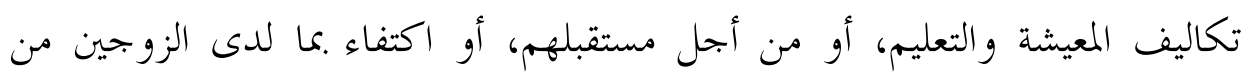
أو لاد- فغير جائز "(r). 


\section{المبحث الثاني \\ نققه المرأة الحامل}

أكرم الإسلام المرأة في جميع حالاتا سواء كانت بنتاً، أو أختاً، أو أماً، أو جدة، أو

زوجة، أو عمة أو خالة، فأوجب لها النفقة لتعينها على مصاعب الحياة، فقد قال اللهّ

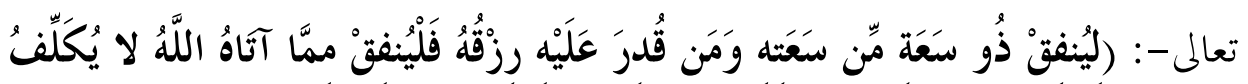

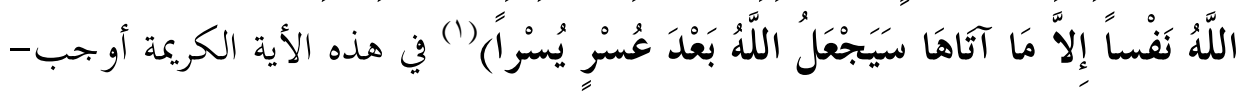

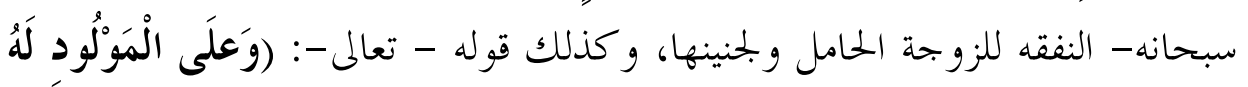

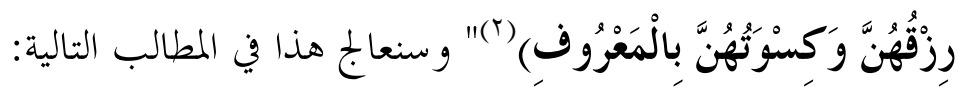
المطلب الأول: نفقة المرأة الحامل المطلقة

النفقة لغة(؟َ): ما أنفق، و النفقة ما أنفقت واستنفقت على العيال، وأنفق القوم نفقت سوقهم و نفق ماله ودرهمه، وأنفق المال صرفه. ويقصد هـا من الناحية الاصطلاحية كما ذكر ابن عابدين: الطعام والكسوة والسكن (؛). ووفي وقتنا الحالي تشمل النفقة الدواء، والاستطباب، وأدوات الزينة، و لا لا تقتصر النفقة على ما ذكر ابن عابدين النفقة، فقيل: هي الإدرار على شيء.بما فيه و بقاؤه، وقيل: هي ما به قوام معتاد دون سرف، وقيل: هي الدراهم والزاد و الذخيرة

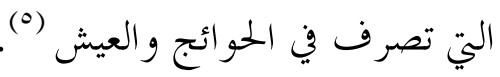
وعرفها د. عمر الأشقر بأها (ما يفرض للزوجة على زوجها من مال للطعام و

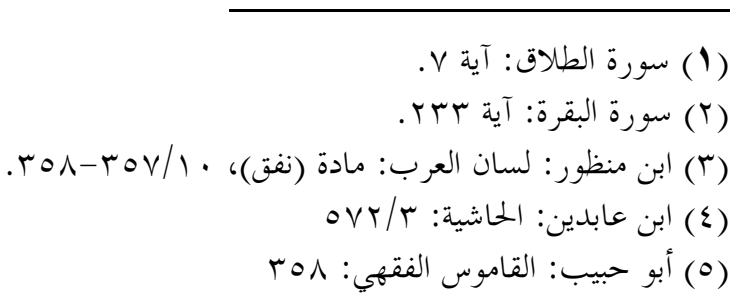


الكساء و السكن والحضانة ونحوها)("). وقد أجمع العلماء(r) على وجوب النفقة للمرأة

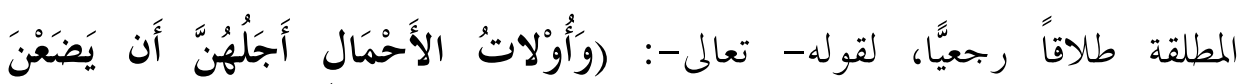
حَمْلَهُنُّنَ) (r) ولأن الولد له. وقد اختلف العلماء في سبب نفقة المرأة الحامل المطلقة طلاقًاً رجعيًّا، فقال البعض لَّل بوجوب النفقة للحمل، وقال البعض بتب النفقة للحامل.

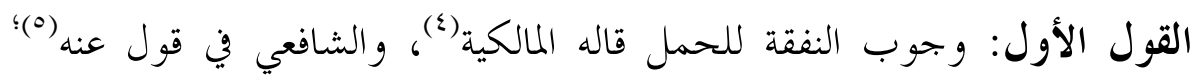
و الحنابلة(7) وذلك للسباب التالية: ا - لأن الولد له فينفق على المرأة الحامل، وقد اشترط المالكية حرية الحمل وحرية أبيه (V)

ץ- بحب للحامل؛ لأها بتجب بوجوده و تسقط عند انفصاله فدل على أها له (^). القول الثاني: بحب للأم الحامل، قاله الشافعي في قول عنه(9) والحنابلة في رواية(·) واستدلو ا.ما يلي: 1- النفقة بحب للأم مع اليسار والإعسار فكانت لها كنفقة الزوجات (1').

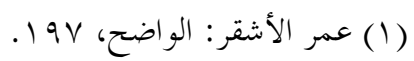

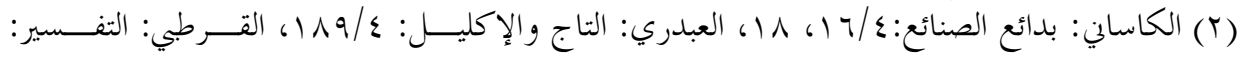

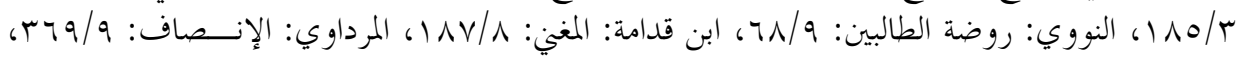

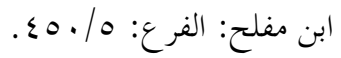
(؟) سورة الطلاق:آية (ع).

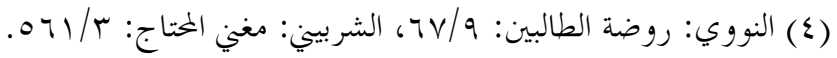

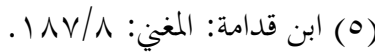

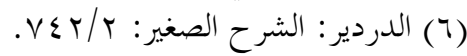

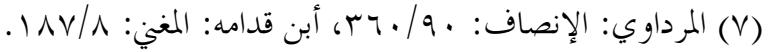

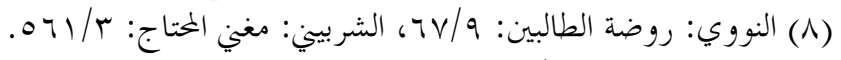

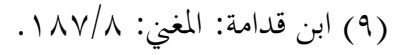

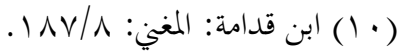

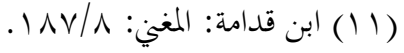


r- لأها لا تسقط مضي الزمان فأشبهت نفقتها في حياته (1). r- لأن النفقة وإن كانت للحمل فهي مصروفة للحامل، وهي صاحبة حق فتصير ديناً كنفقة الزوجة (r)

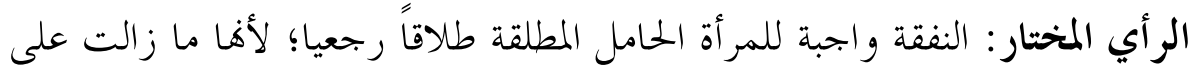
ذمة زوجها، سواء كانت النفقة من أجل الأول أو الولد، فإن منفعة النفقة بجميع أحو الها تعود على الأول ومن ثنم على الولد، و كذلك لأن التغذية للحمل تغذيةٌ للأم.

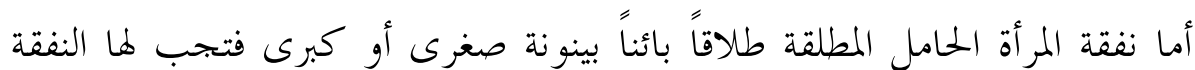

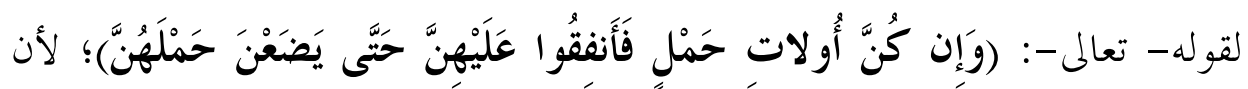
النفقة بتجب للحمل ولأن المرأة البائن محبوسة لحقه (َ).

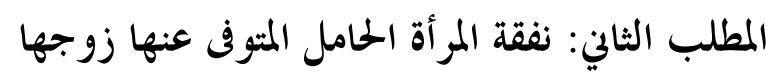
اختلف العلماء في نفقة المرأة الحامل المتوفى عنها زوجها على عدة أقوال: القول الأول: لا نفقة لما ولا كسوة ولا سكنى، قال هذا القول جابر بن عبد الله

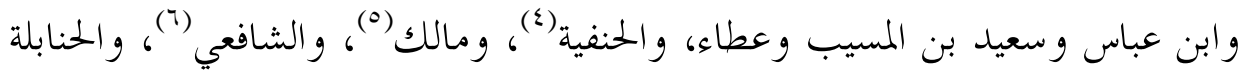

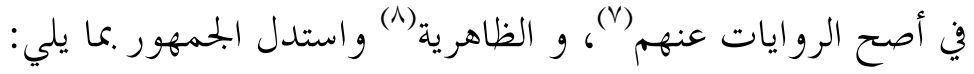
المعقول:

أ- لما تم الإجماع على أن الميت تسقط عنه نفقة زوجته وأطفاله فكذلك تسقط

$$
\begin{aligned}
& \text { (1) النووي: روضة الطالبين: TV/9. }
\end{aligned}
$$

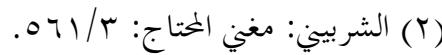

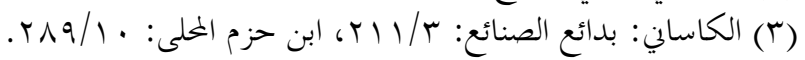

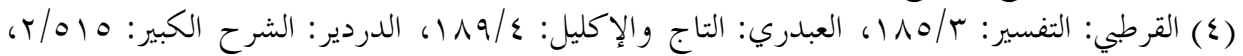

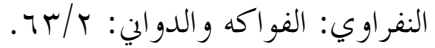

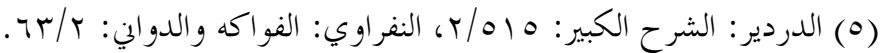

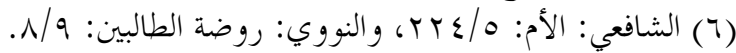

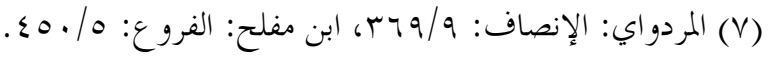

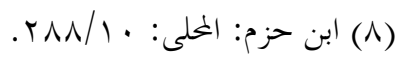


عنه نفقة الحامل من أزو اجهه (1).

ب- نفقة الحمل ليست بدين ثابت متعلق .ماله بعد موته بدليل أها تسقط عنه

$$
\text { بالإعسار، فسقوطها بالموت أولى (r). }
$$

ج- لأن المال قد صار للورثة، ونفقة الحامل و سكناها إنما هو للحمل أو من أجله و لا يلزم ذلك الورثة، وإن كان للميت ميراث فينفق على الحمل من نصيبه(r). د- النفقة تسقط؛ لأن المرأة الحامل كالحاضنة للولد ولا بتجب نفقة الحاضنة بعد

الموت، وإن قيل النفقة للحمل فإنا تسقط لأن نفقة القريب تسقط بالموت (ع). القول الثاين: لها النفقة والسكنى والكسوة، وقال هذا القول: علي وعبد الله بن عمر - رضي الله عنهم- وشريح وابن سيرين (0)، وعبد الله بن مسعود، ووفي رواية عن

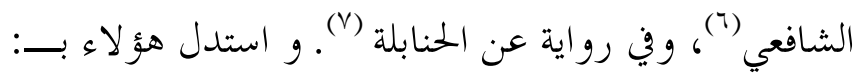

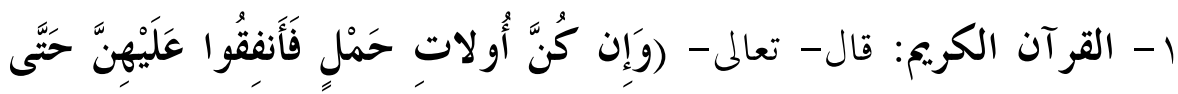

يُضَعْنَ حَمْلَهُنَّن) وهذه الآية عامة في المتوفى عنها زو جها و المطلقة (^). r- المعقول: أن الزوجة محبوسة لحق الميت فتجب نفقتها في ماله (9).

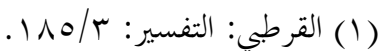

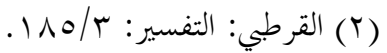

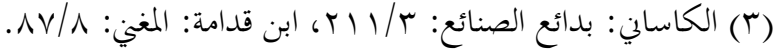

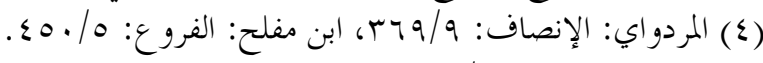

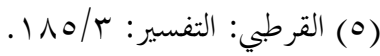

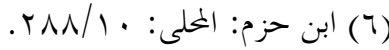

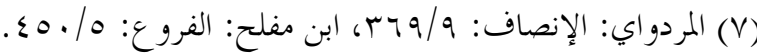

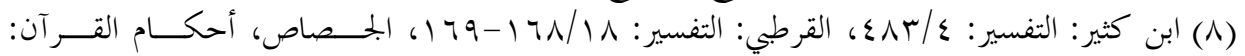

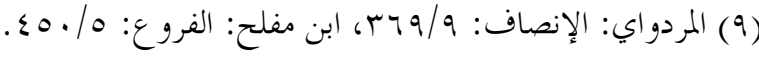


r- ها السكني فقط و هذا ما قاله بعض المالكية(') و ورواية عن الحنابلة(「).

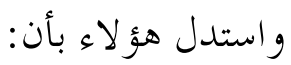

أ) السكنى: لا تسقط السكنى؛ لأفها لا تسقط بالموت ولا بالطلاق البائن (").

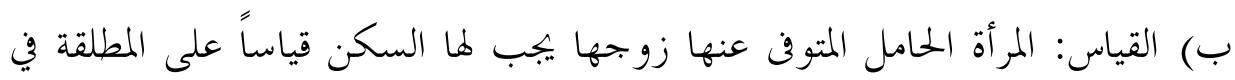
حالة حياته (๕)

الرأي المختار: لا نفقة للحامل المعتدة بسبب الوفاة؛ لأن النفقة تسقط بالوفاة، وها أن تنفق من التركة من نصيبها، ولها أن تسكن في مسكن زوجها المملوك له أو المستأجر وقد دفع أجرته قبل موته، وذلك لحديث الفريعة بنت مالك وقد أمرها- عليه الصلاة والسلام- أن تعتد في مسكنها، فقال لها: "امكثي في بيتك حتى يبلغ الكتاب أجله" فقال: فاعتدت فيه أربعة أشهر وعشراً"(0). ويرد على من استدل بالمعقول: بأن الزوجة محبوسة لحق الميت فتجب نفقتها في

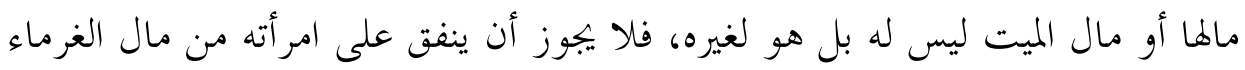

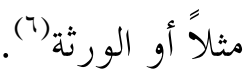

\section{المطلب الثالث: نفقة المرأة الحامل في شبهة}

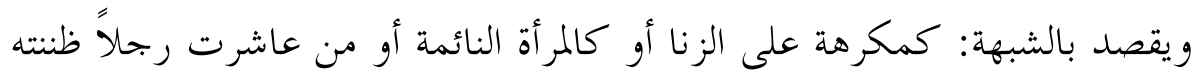

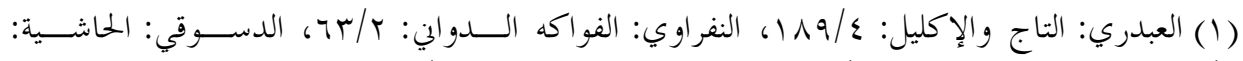

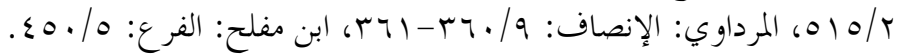

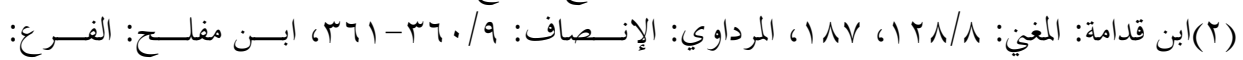
. $\{0.10$

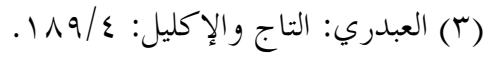

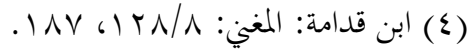

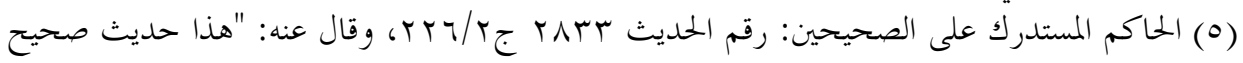

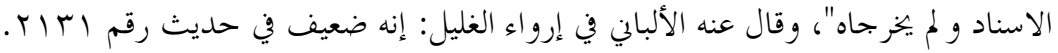

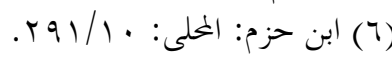




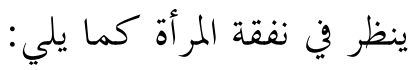

إن تم معاشرقا مكرهة أو هي نائمة فيلزم المعاشر النفقة(؟)، وقد فرق الشافعية في

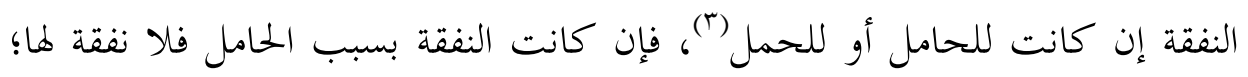
لأنه لا نفقة لها حال التمكين فبعده أولى، وإن كان بسبب الحمل فقد قيل بحب النفقة؛ لأنه يلزمه نفقته بعد انفصال الحمل؛ لذا يجب أن تلزمه قبل انفصال الحمل (ع). وإن ظنت أن معاشرها هو زوجها و لم يكن كذلك، فلا يلزمه النفقة عند الحنابلة(0) وإن ظهر أها حملت من غير زوجها كالحمل نتيجة للزنا فلا نفقة على بلى

$$
\text { الزوج؛ لأن حملها من غيره (ج) }
$$

الرأي المختار: أرى أن من تم معاشرقا مكرهة أو وهي نائمة أها لا تريد الزنا فلا تسمى زانية، فإن حملت وجب لها النفقة؛ لأها تحمل في أحشائها ولد الفاعل وإن و وجد بطريقة غير شرعية، فإن اعترف به بتب نفيه نفته عليه.

\section{المطلب الرابع: نفقة المرأة الحامل الناشز}

إذا نشزت المرأة و كانت حاملاً فهل ها نفقة؟ قال الحنفية(V)، و المالكية(^) بسقوط نفقة الناشز.

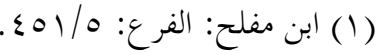

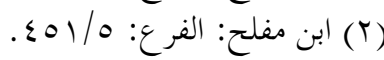

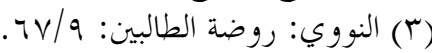

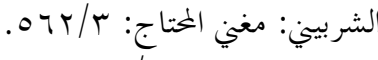

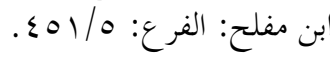

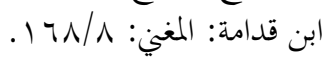

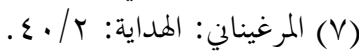

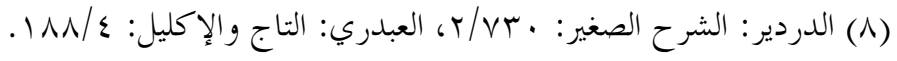


وعند الشافعية(') تسقط النفقة للحمل والحامل، واستدل هؤلاء بأن النفقة تسقط

$$
\text { لنشوزها. }
$$

$$
\text { وأما الحنابلة فقد فقرقوا بين أمرين: }
$$

إن كانت النفقة للحمل فلا تسقط النفقة، واستدلوا بأن نفقة الولد لا تسقط

بنشوز أمه الحامل به (r) وإن كانت النفقة للحامل فلا نفقة ها؛ لأفها ناشز (r). ***

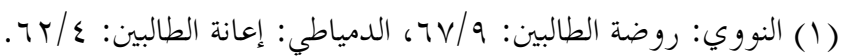

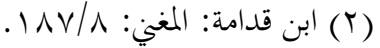

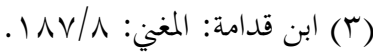




\section{المبحث الثالث \\ أكثر الحمل وأقله}

إن معرفة أكثر الحمل وأقله وتقدير هذه المدة له دور في معرفة أن الحمل من نكاح

شرعي أو من سفاح، وقد اهتم الفقهاء بذلك.

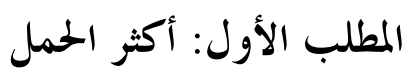

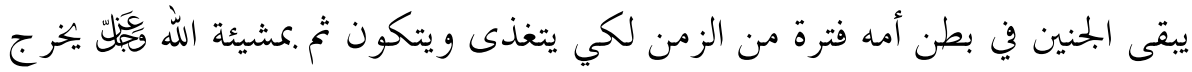
هذا الجنين ليؤدي دوره في الحياة، وقد اختلف الفقهاء في الفترة التي يقضيها الجنين في بطن أمه، ولكنهم اتفقوا على أن غالب المدة هي تسعة أشهر وكانت نتيجة هذا الاختلاف كما يلي:

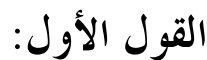

1- يبقى الجنين في بطن أمه خمس سنوات، قاله المالكية(1)، و القاضي حسين من

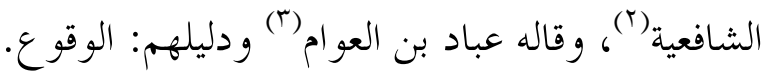

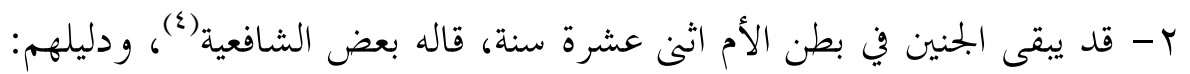

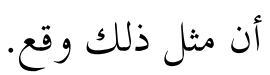

r- يبقى الجنين في بطن أمه أربع سنوات، قاله مالك(م) في رواية عنه، وقاله الغزالي و الشافعي (†)، وظاهر الحنبلي (V).

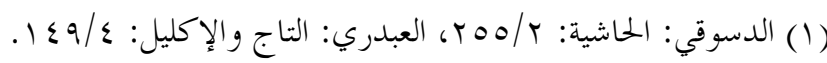

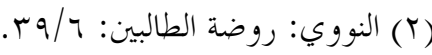

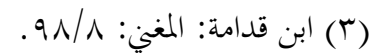

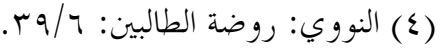

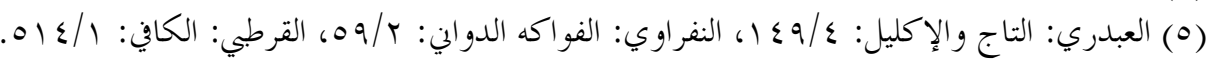

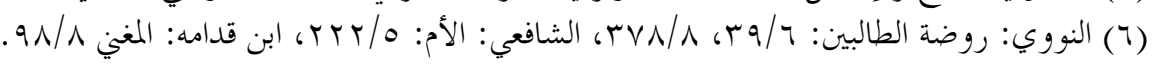

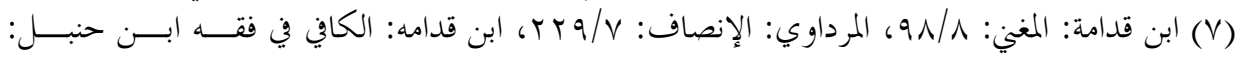




\section{وقد استدل هؤلاء بأن الواقع يؤيد ذلك(1):}

أ- روي أن مالك قال: هذه جارتنا امرأة محمد بن عجلان تحمل أربع سنين قبل أن تلد (r)، وقال الشافعي: "بقي محمد بن عجلان في بطن أمه أربع سنين"((r)، وقال أحمد: "نساء بني عجلان يحملن أربع سنين وامرأة عجلان حملت ثلاث بطون كل بل بن

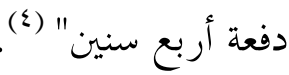
ب-وروي عن عمر أنه ضرب لامرأة المفقود أربع سنين و لم يكن ذلك إلا لأنه غاية الحمل "(0). ج- روي عن سعيد بن المسيب قال: "إن أبا هذا غاب عن أمه أربع سنين، ثم قدم

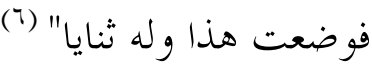
ع - ثلاث سنوات، قاله الليث (v). استدل لذلك بأن مالك بن أنس حملت به أمه ثلاث سنوات (^). ه- ست سنوات وسبع سنوات، قاله الزهري(9).

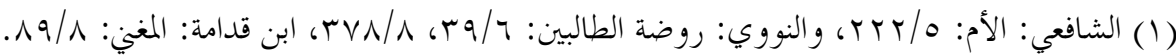

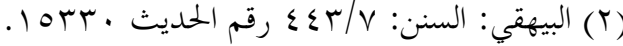

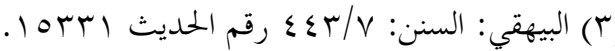

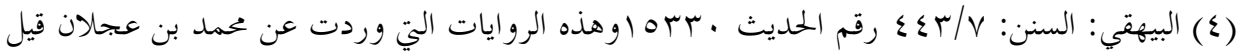

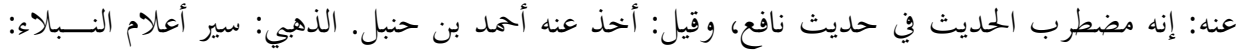
$.419 / 7$ (0) قال ابن حزم: "والذي أوردنا عن عمر وعثمان أن امر أة المفقود تتربص أربع سنين وأربعة عشر شهرا

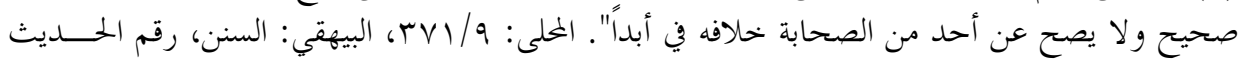
إ

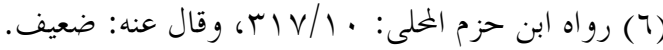

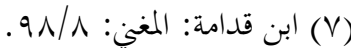

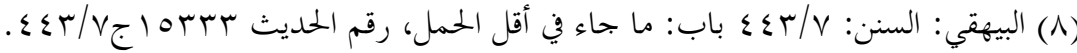

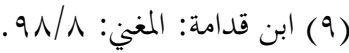


ج- وقيل لا يوجد وقت لأكثره، قال أبو عبيدة(1).

القول الثالي: يرد على من قال إن الجنين يمكث في بطن أمه أكثر من أربع سنوات بحديث السيدة عائشة أفا قالت: "لايبقى الولد في رحم أمه أكثر من سنتين ولو

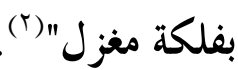
و جه الدلالة: نفي بقاء الجنين أكثر من حولين إذ قالت السيدة عائشة هذا سماعاً

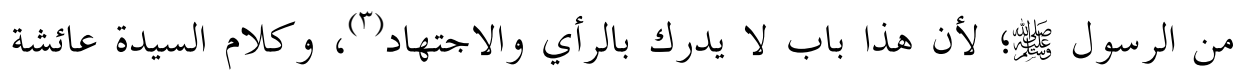
- رضي الله عنها- لا يثبت بالرأي كالمقادير؛ لذا يكون حكمه حكم المرفوع، وبناء” على ذلك لو أتت بالولد لأكثر من أربع سنوات من يوم طلاقها، فلا ينسب الولد لأ بيه (ع) و استدل هؤلاء .ما يلي: ا- روت جميلة بنت سعد عن عائشة: "لا تزيد المرأة على السنتين في

r- رفع إلى عمر بن الخطاب أن امرأة غاب عنها زوجها سنتين، فجاء وهي حبلى، فهم عمر برهمها، فقال له معاذ بن جبل: يا أمير المؤمنين، إن يك السبيل عليها، فلا سبيل لك على ما في بطنها، فتر كها عمر حتى ولدت غلاماً قد نبتت

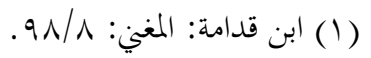

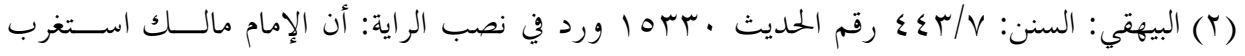

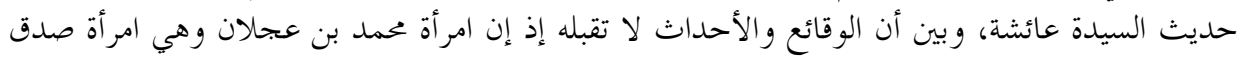

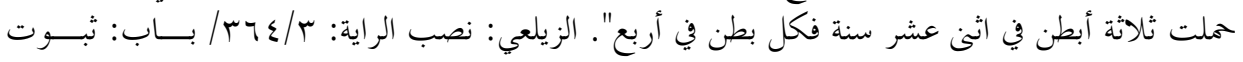

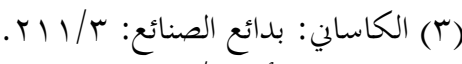

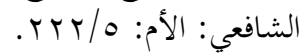

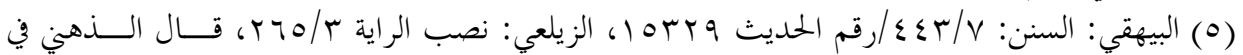

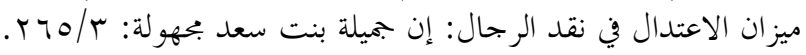


ثناياه، فعرف زوجها شبهه فقال عمر : عجز النساء أن يلدن مثل معاذ، هلك عمر (1).

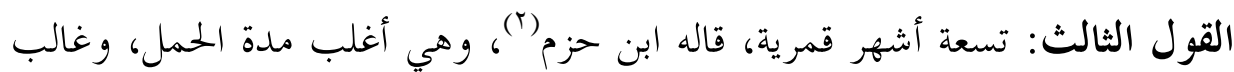
النساء يحملن كذلك، وهو أمر معروف بين الناس.

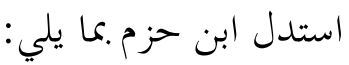

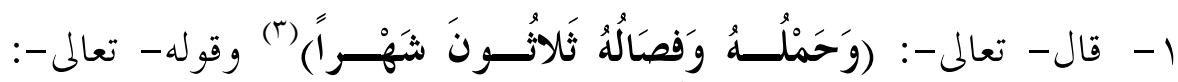

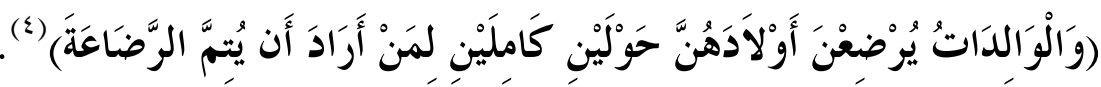

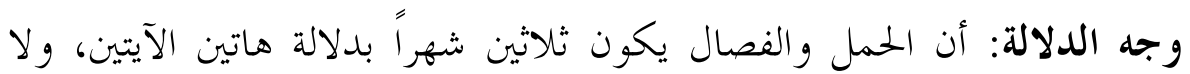
يكون أكثر من ذلك، ومن قال بأن الحمل و الفصال يكون أكثر من ثلاثين شهراً فقد رد كلام الله - تعالى - (0)

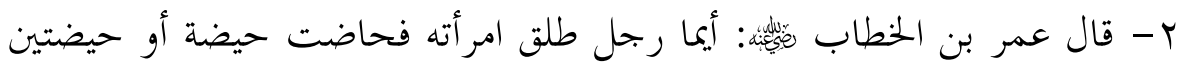
ثم قعدت فلتجلس تسعة أشهر حتى يستبين حملها، فإن لم تستبن حملها في تسعة أشهر، فلتعتد بعد التسعة الأشهر ثلاثة أشهر التي قعدت من المحيض" "("). r- أن الحمل مدة تسعة أشهر يصدقه الواقع. أما بالنسبة للوقت الذي تحسب منه المدة، فقد قيل: يحسب الحمل من وقت الفراق، وقيل: من إمكان العلوق، وقيل: من وقت انتهاء العدة (V).

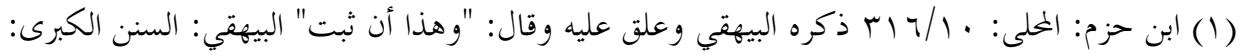

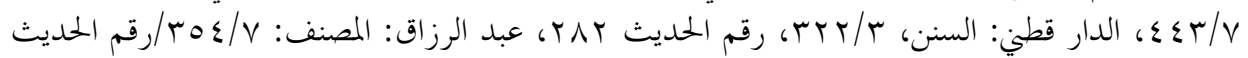
$.1 r \leqslant 0 \leqslant$

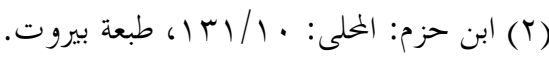

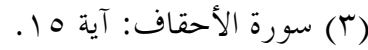

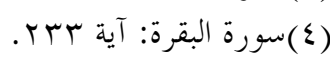

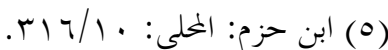

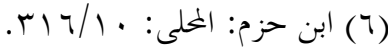

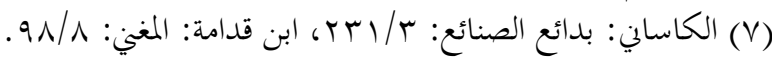

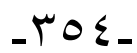


الرأي المختار: أن الواقع والذي يقبله العقل - هو قول ابن حزم، ويرد قول غيره

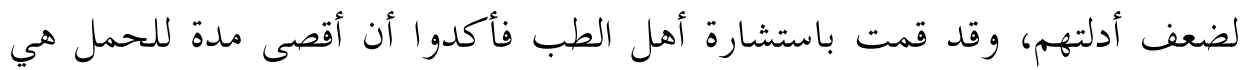

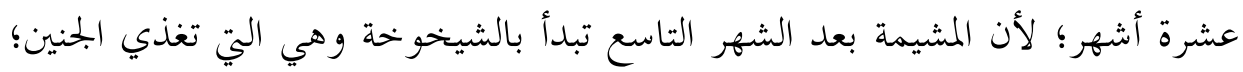

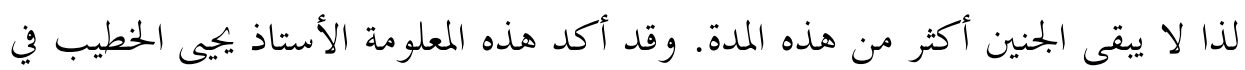

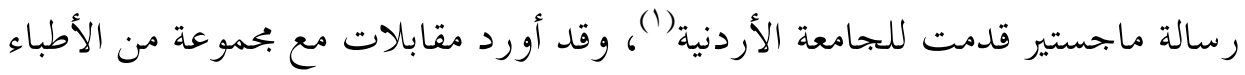

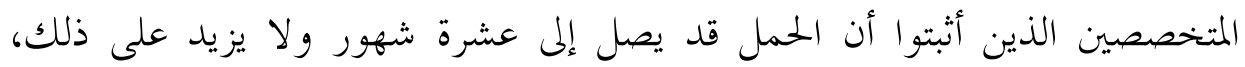
وغالبية النساء يصل الحمل عندهن إلى الشهر التاسع.

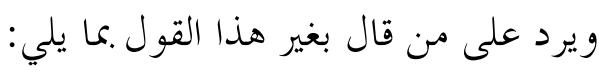

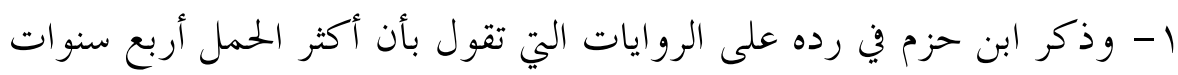

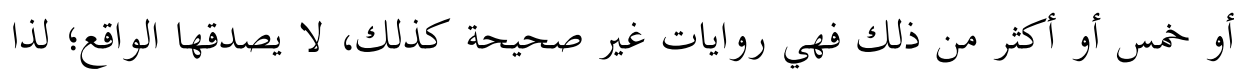

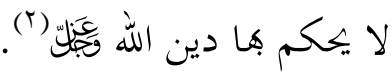

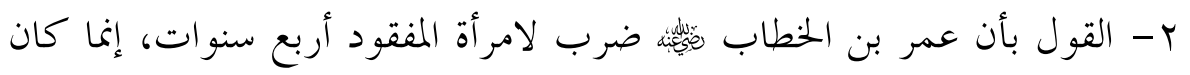

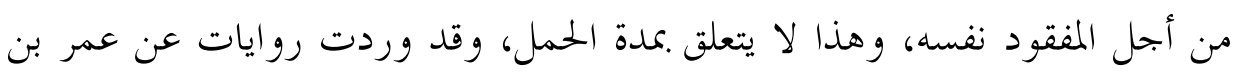

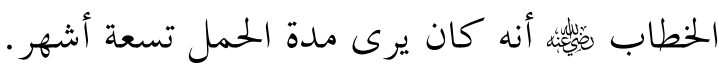

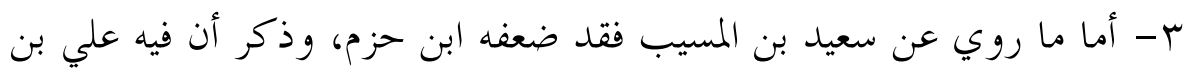

زيد بن جدعان وهو ضعيف ("). ع - أما ما روي عن عمر فهو حديث باطل؛ لأنه عن أبي سفيان وهو ضعيف عن

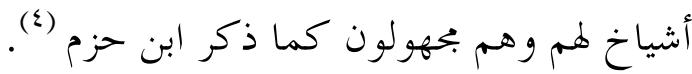

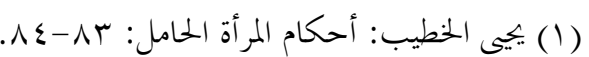

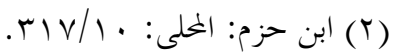

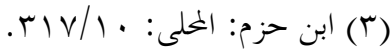

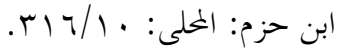




\section{ه- أما حديث جميلة فقد ذكر ابن حزم أها بحهولة(1). \\ المطلب الثاني: أقل مدة الحمل}

لقد اتفق الفقهاء(r) على أن أقل مدة الحمل هي ستة أشهر، وفي وقتنا الحاضر من

$$
\begin{aligned}
& \text { يولد قبل تمام الحمل فإنه يوضع في الخداج. } \\
& \text { واستدلو ا.بما يلي: }
\end{aligned}
$$

1- أن أبا الأسود قد قال: رفع إلى عمر أن امرأة ولدت لستة أشهر فهم برجمها

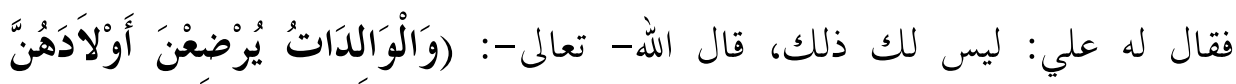

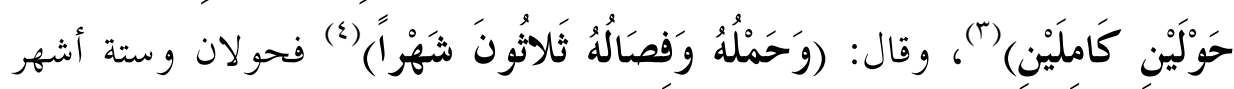
ثلاثون شهراً لا رجم عليها فخلى عمر سبيلها وولدت مرة أخرى لذلك الحس الحد (0).

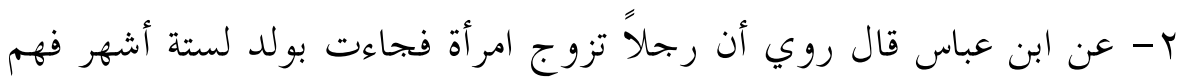

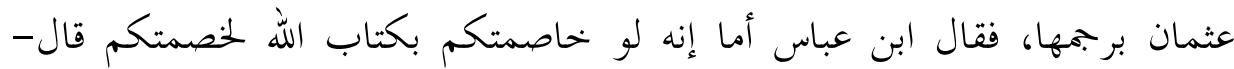

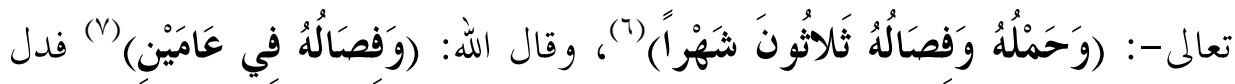
على أن أقل مدة حمل هي ستة أشهر فهي تحمله ستة أشهر وترضعه حولين كاملين (م). مع أن الفقهاء اتفقوا على أن أقل مدة للحمل هي ستة أشهر، ولكنهم اختلفوا في

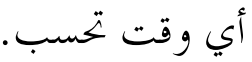

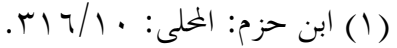

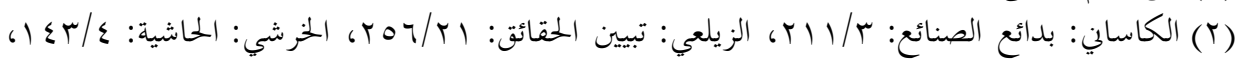

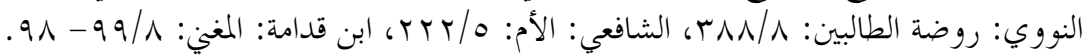

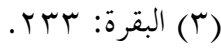

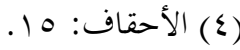

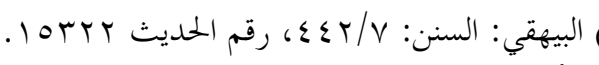

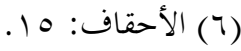

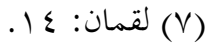

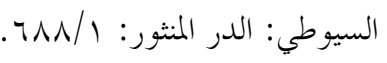


قال الجمهور: يحسب من وقت الدخول وإمكان الوطء؛ لأن المرأة ليست بفراش

$$
\text { إلا عند الدخول (1) }
$$

وقال الحنفية: الوقت يحسب من وقت عقد الزواج بخلاف زفر؛ لأن المرأة هي

$$
\text { فراش الزوج ويلحقه الولد لحديث: "الولد للفراش" (r). }
$$

الرأي المختار: يحسب من وقت الدخول وإمكان الوطء لا من وقت العقد؛ لأن المرأة ليست بفراش إلا عند الدخول. 


\section{المبحث الرابع \\ علدة المرأة الحامل}

تجب العدة على المرأة الحامل المسلمة أو الكتابية بسبب الموت أو الطلاق أو الفسخ، وتنتهي هذه العدة بوضع الحمل اتفاقاً (1)؛ لقوله- تعالى - (وَأُوْلاتُ الأَحْمَال

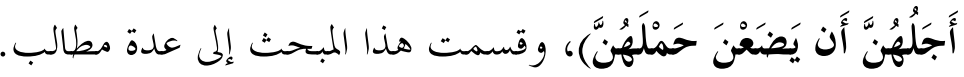

المطلب الأول: عدة المر أة الحامل المتوفى عنها زوجها

اتفق جمهور الفقهاء(ז) على أن عدة المرأة المتوفى عنها زوجها إذا كانت حاملاً تنتهي بوضع الحمل، وخحالف في ذلك ابن عباس وعلي وقالوا: إذا تعتد بأقصى

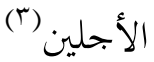

وذكر أن الحسن والشبي قالوا: إن عدها تنتهى حين تطهر، ولكن هذا القول لم

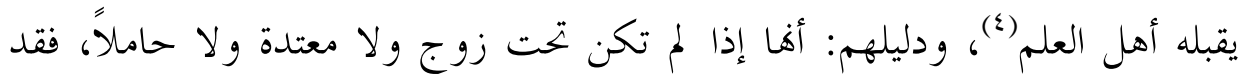
خلت من الموانع الشرعية فتحل ضرورة ولكن لا يطؤها حتى تطهر (0). واستدل جهمور الفقهاء.بما يلي:

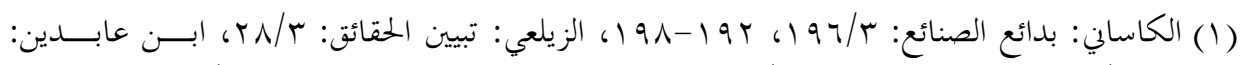

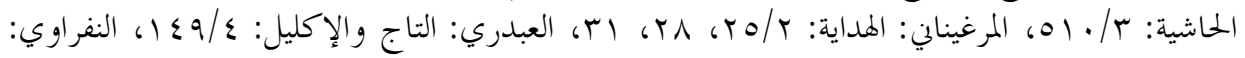

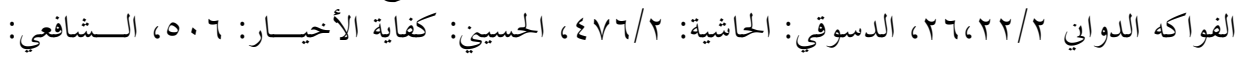

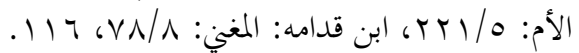

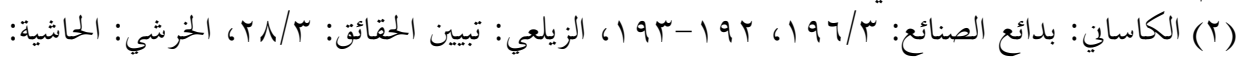

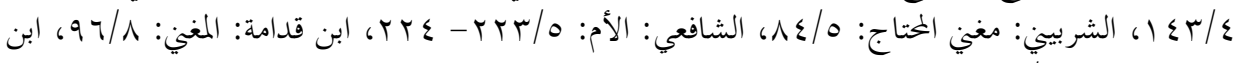

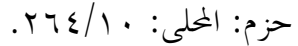

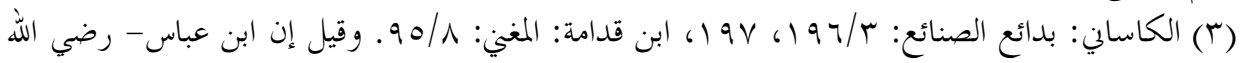

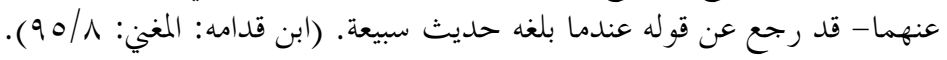

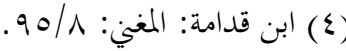

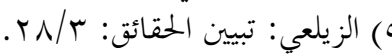




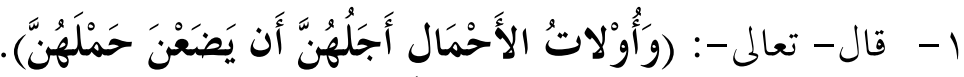
وجه الدلالة: بينت الآية الكريمة أن عدة المرأة الحامل المتوفى عنها زوجها هي المها

بوضع حملها ولو بعد وفاته بساعة('). r- عن عبد الله بن الأرقم أن سبيعة الأسلمية أخبرته أها كانت تحت سعد بن خولة وتوفى عنها في حجة الوداع وهي حامل فلم تنشب أن وضعت حملها بعد وفاته، فلما تعلت من نفاسها بحملت للخطاب فدخل عليها أبو السنابل بن بعكك، فقال: مالي أراك متجملة لعلك ترجين النكاح، أنك والله ما أنت بناكح حتى تمر لهاب عليك أربعة أشهر وعشر، قالت سبيعة: "فلما قال لي ذلك جمعت على ثيابي حتى

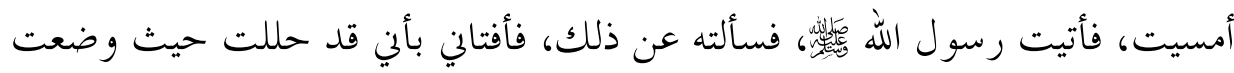

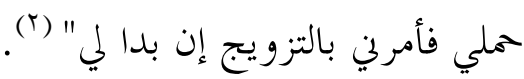
وجه الدلالة: أفتى - عليه السلام- سبيعة المتوفى عنها زوجها أن تنكح إن بدا لها، وفي هذا دلالة على أن المرأة الحامل متى وضعت حملها حلت للأزواج. r- الهدف من العدة معرفة براءة الرحم من الحمل، وبوضع الحمل تعرف البراءة؛ لذا تنقضي العدة (r) القول الثالي: تعتد بأبعد الأجلين، قاله علي بن أبي طالب و ابن عباس- رضي الله

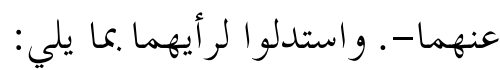

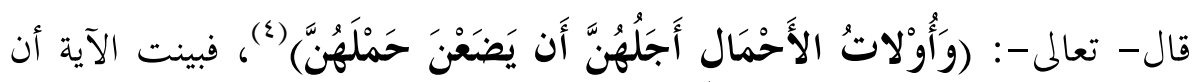
الاعتداد بوضع الحمل ذكر في الطلاق لا الوفاة، ولأنه معطوف على قوله: (وَاللآَّئي

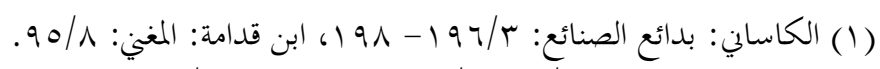

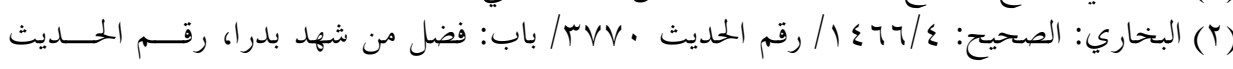

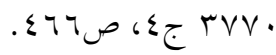

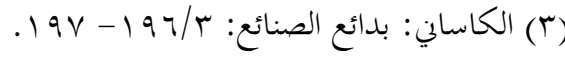
(ع) سورة الطلاق: آية (0). 


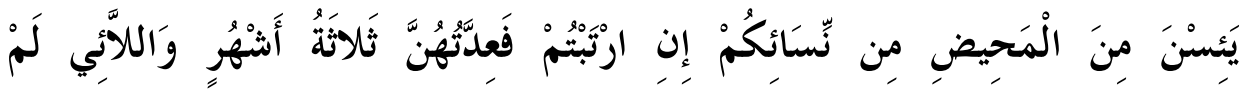

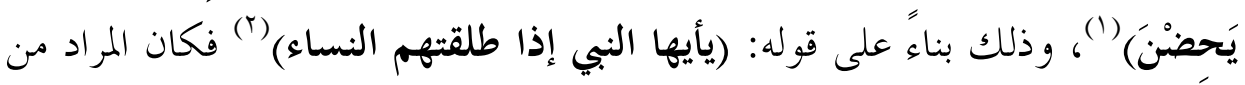

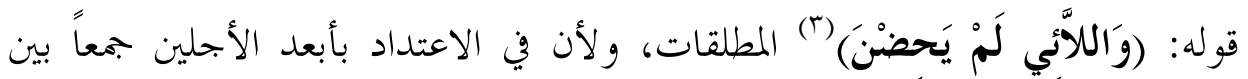

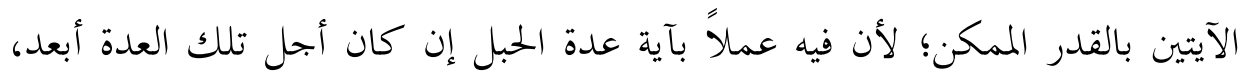

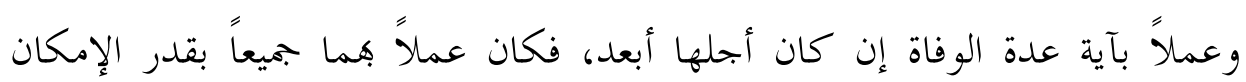

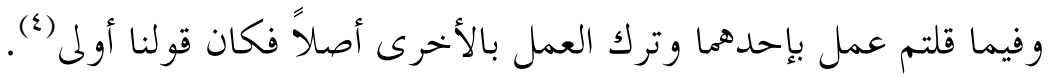

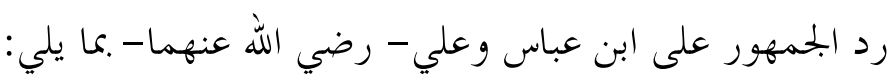

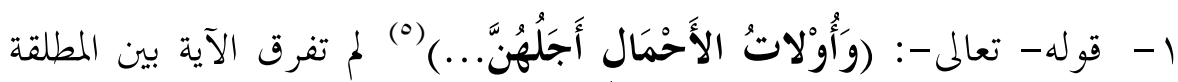

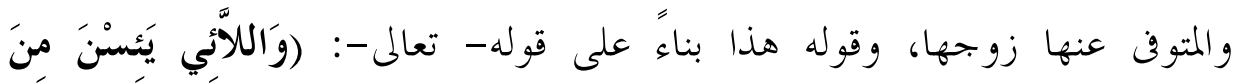

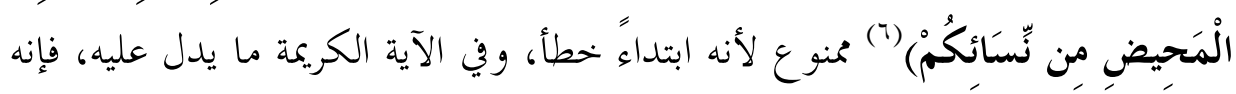

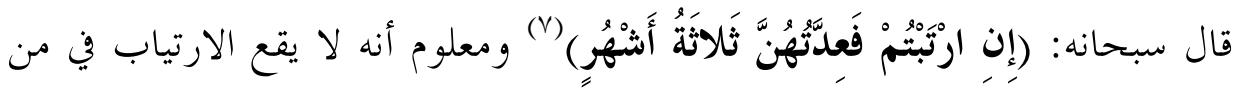

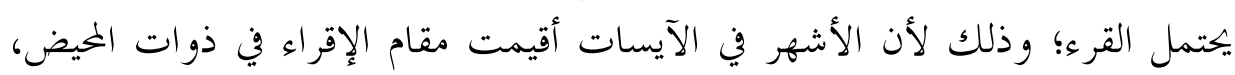

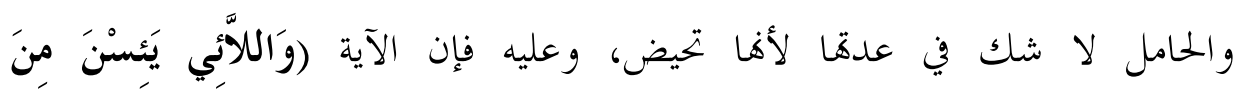

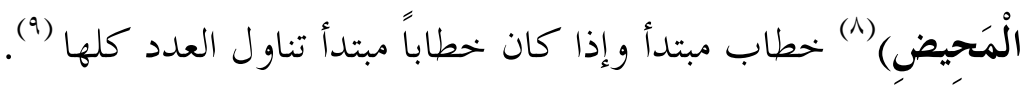

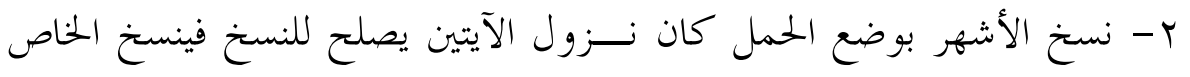

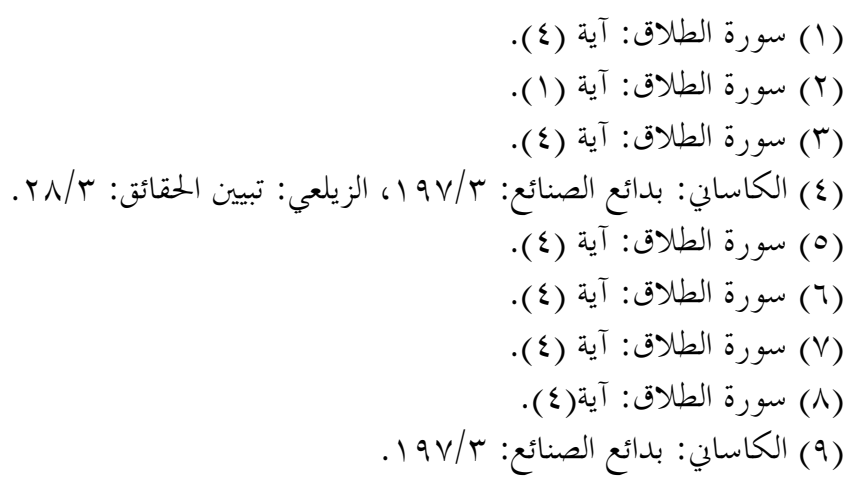


المتقدم بالعام المتأخر ولا يبين العام على الخاص، أو يعمل بالنص العام بعمومه ويتوقف في حقه الاعتقاد في التخريج على التناسخ ولا ينبنى العام على الخاص (1). r- المقصود من العدة: براءة الرحم، ووضع الحمل فيه الدلالة على البراءة وهو أولى من انقضاء المدة(؟). الرأي المختار: أرى أن رأي الجمهور هو الرأي الراجح؛ لقوة أدلتهم التي استدلوا بها، و الله أعلم.

\section{المطلب الثاني: أحوال الحمل الذي تنقضي به العدة}

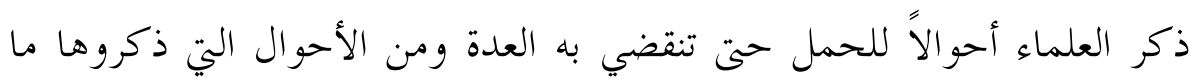

1- ما تبين فيه شيء من خلق الإنسان، وبه تنقضي العدة بلا خلاف (r).

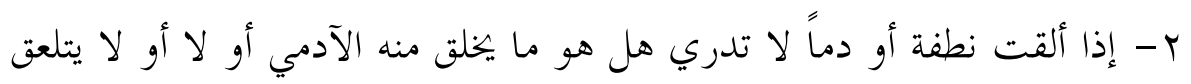
به شيء من الأحكام؛ لأنه لم يثبت أنه ولد لا بالمشاهدة ولا بالبينة، وعليها أن

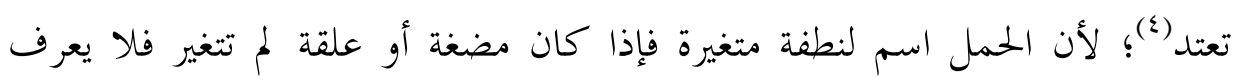
كوها متغيرة بيقين إلا باستبانة بعض الحلق (0). r- إذا ألقت مضغة لم تبين فيها الخلقة فشهد ثقات من القوابل أن فيه صورة

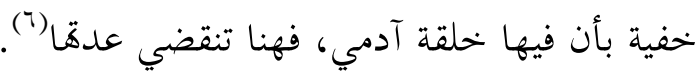
ع - إذا ألقت مضغة لا صورة فيها، وشهد ثقات من القو ابل أنه مبتدأ خلق آدمي،

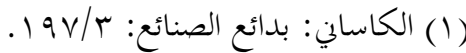

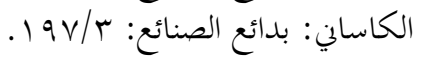

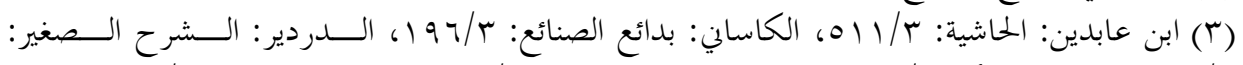

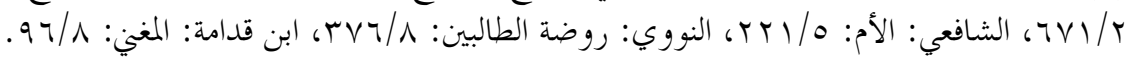

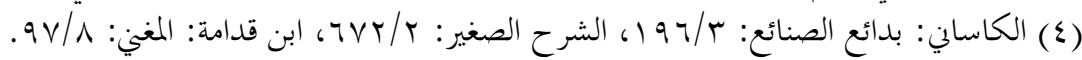

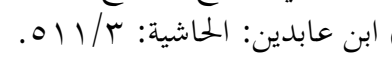

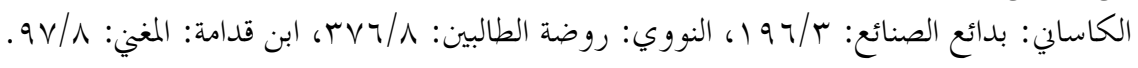


فقد اختلف في هذه المسألة على أقوال:

أ) قال الحنفية والشافعي وأممد: لا تنقضي العدة؛ لأنه لم يبين خلق آدمي وهذا فيه شكك (1)

ب) وفي رواية عن الشافعية(r) وبعض الحنابلة(r) أن العدة تنقضي به؛ لأفم شهدوا

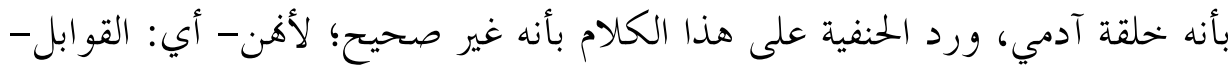
لم يشاهدن انخلاق الولد في الرحم ليقاس هذا عليه (s).

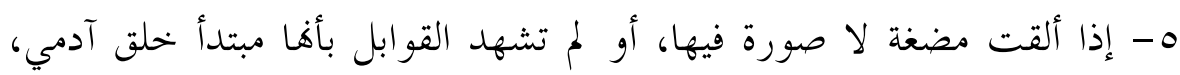

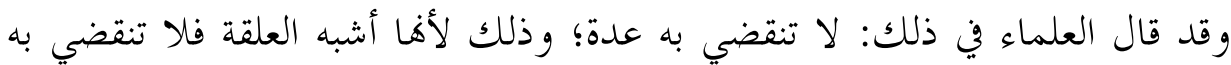

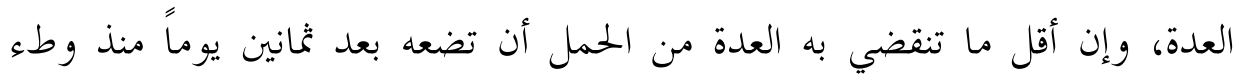

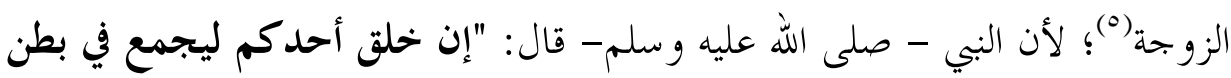

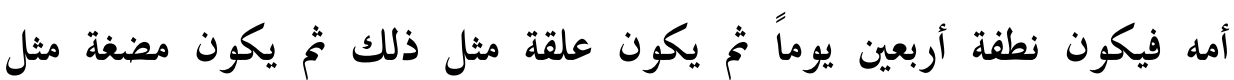
ذلك" (`)

وجه الدلالة: أن العدة لا تتنفي بما دون المضغة فوجب أن تكون بعد الثمانين(v). ***

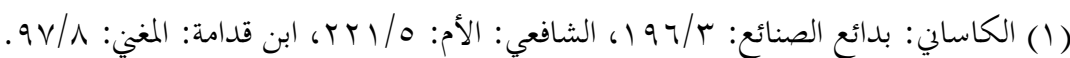

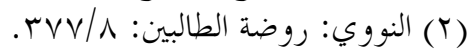

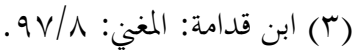

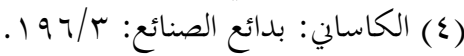

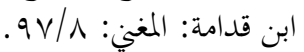

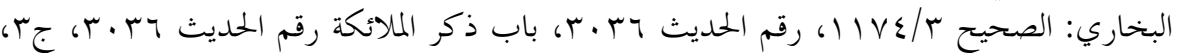




\section{الخاتهت}

في فاية هذا البحث أذكر أهم النتائج التي توصلت إليها وهي كما يلي: 1- الشريعة الإسلامية صالحة لقيادة البشرية؛ لأنه لم تنـزل شاردة ولا واردة إلا لإئ بينت حكمها. r- اهتم الإسلام بالمرأة اهتماماً كبيراً، فقد اهتم هـا بنتاً وأمَّا وأختاً وزوجةً ومطلقة، وبين الأحكام التي تتعلق هـا وأعطاها من الحقوق التي تحقق لها إنسانيتها. r- يحافظ الإسلام على الحياة الزوجية، ويأبى أن تكون العلاقة بينهما غير شريعة؛ لذا لذا لـئي أولى لها من الأحكام التي تصوفا. ع - نكاح المرأة الحامل من الزنا محرم حتى تبرأ من حملها.

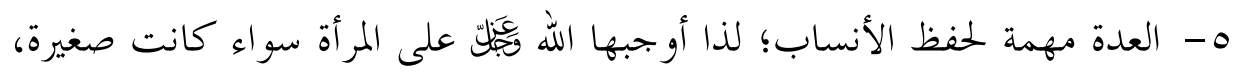
أو كبيرة، أو آيسة، أو حاملاً.

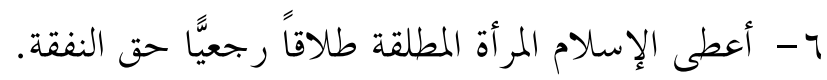
- - ل ال نفقة للحامل المعتدة بسبب الوفاة. - - تصح ملاعنة المرأة الحامل. 9- - مدة أكثر الحمل تسعة أشهر كما قرر العلم الحميث، وأقله 7 أشهر.

وفي النهاية أقول هذا جهد متواضع أسال الله له القبول.... فإن أصبت فمن الله وإن أخطأت فمن نفسي..... و الله ولي التوفيق. ** * 


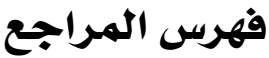

1- القران الكريم. .

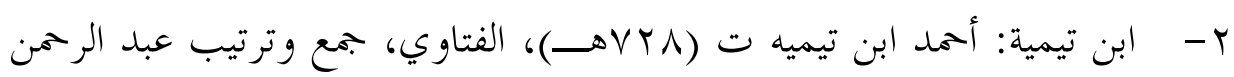
المجدي.

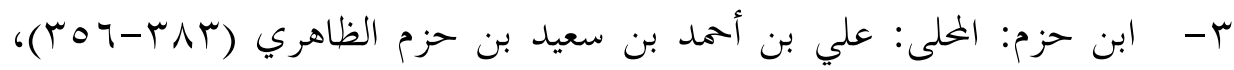
دار الآفاق الجحيدة، بيروت، لجنه إحياء التراث العربي، وطبعه دار الكتب بن

العلميه، 9191.

ع - ابن عابدين: حاشيه ابن عابدين، دار الفكر للطباعه، بيروت، اب إهـ اهـ. ه- - ابن قدامة: عبد الله بن قدامة، الكافي في فقه ابن حنبل بيروت، المكتب

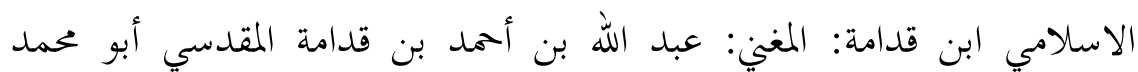

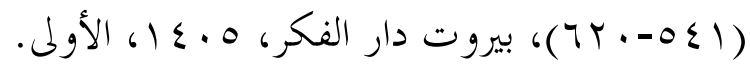

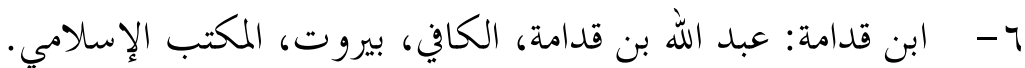
- - ابن منظور: أبو الفضل جمال الدين محمد بن مكرم بن منظور، لسان العرب،

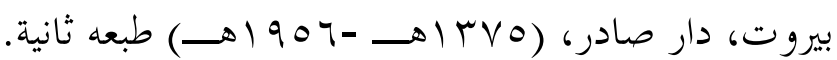
^- ابن مفلح: محمد بن مفلح المقدسي أبو عبد الله (VTY-VIV)، الفروع المققق أبو الزهراء حازم القاضي، بيروت، دار الكتب العلميه، مإ؛ اهــ، الطبعة الأولى. 9- ابن الهمام: كمال الدين بن الهمام (IN))، شرح فتح القدير بيروت، دار

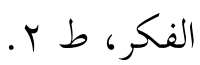

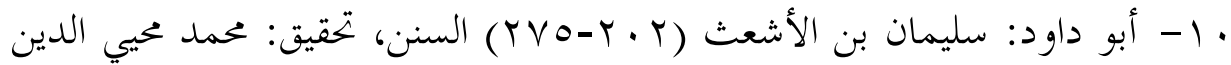
دار الفكر. 


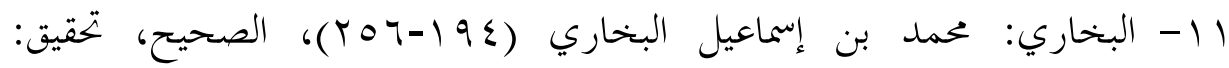

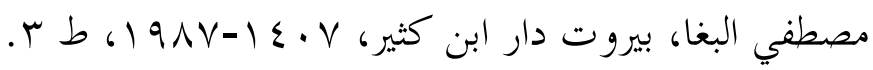

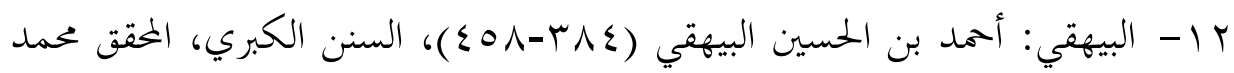

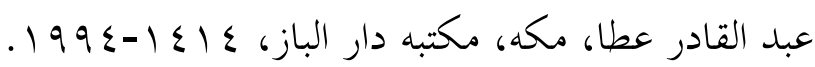

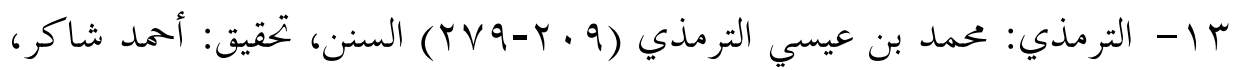
بيروت دار إحياء التراث.

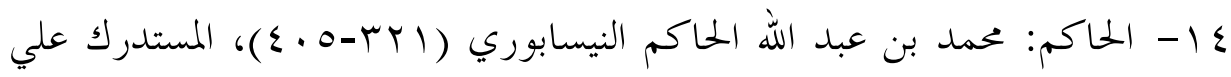
الصحيحين، تحقيق: مصطفى عبد القادر عطا، بيروت، دار الكتب العلميه

$$
.1 \text { b } 6199 \cdot-1 \leq 11
$$

ه - الحسيني: تقي الدين أبو بكر بن محمد الحسيني، كفايه الأخيار، تحقيق: علي

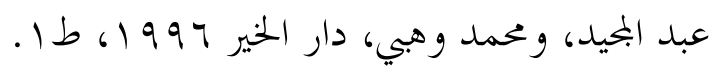
7 ا 1 - الدردير: أبو البركات أحمد بن محمد بن أحمد، الشرح الصغير، و بالهامش حاشية الصاوي، خرج أحاديثه مصطفي كمال، مصر، دار المعارف.

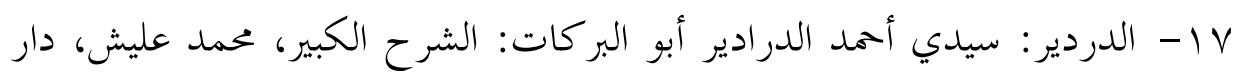
الفكر، الدمياطي: أبو بكر السيد محمد، وإعانه الطالبين، بيروت.

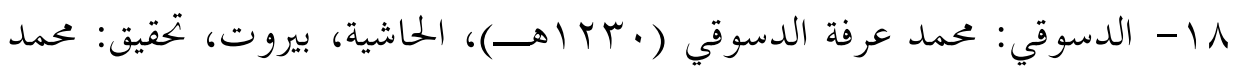
عليش، بيروت دار الفكر.

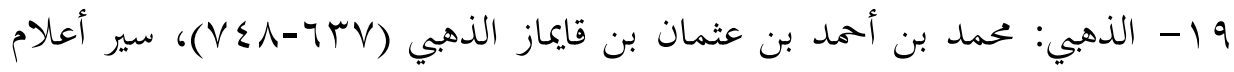
النبلاء، تحقيق: شعيب الأرناؤوط، محمد نعيم العرقسوسي، بيروت، مؤسسة

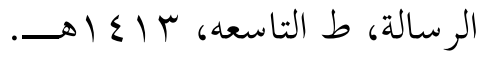
• ץ- الذهبي: محمد بن أحمد ت (V乏^)، ميزان الاعتدال في نقد الرجال، تحقيق: علي محمد معوض وعادل أحمد، بيروت، دار الكتب العلمية، 990 ام. 
ا ا- - الزيلعي: فخر الدين عثمان بن علي الزيلعي، تبيين الحقائق، القاهرة، دار الكتب

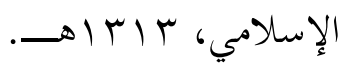

Y

محمد يوسف البنوري، مصر، دار الحديث هVT I هــ.

r ا - السيوطي: عبد الحمن بن الكمال السيوطي (1 11 هــ)، الدر المنثور، بيروت،

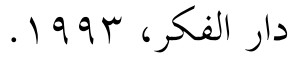

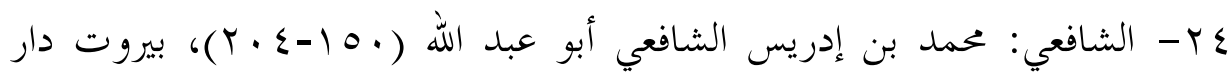
المعرفه بوه اهـــ، الثانيه.

ه - الشافعي: محمد بن إدريس أبو عبد الله الشافعي (0. اهــ - ع •rهـ)، المسند، بيروت، دار الكتب العلميه.

جr- الشربيني: شمس الدين محمد بن الخطيب الشربيني، مغني المحتاج، أشرف على

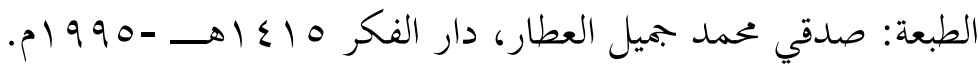
V - عمر الأشقر: الواضح في شرح قانون الأحوال الشخصية الأردلي، الأردن، دار

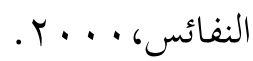

^ץ - القرطبي: يوسف بن عبد الله بن عبد البر (rآع ت)، الكافي، بيروت، دار

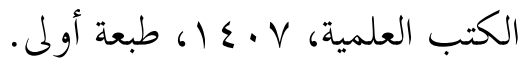

و - القرطي: أبو عبد الله محمد بن أحمد الأنصاري القرطبي، تفسير القرطبي، القاهرة، دار الشعب. • r- الكاساني: علاء الدين الكاساني (ONV)، بدائع الصنائع، بيروت دار الكتاب

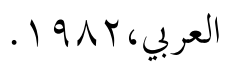

اس- مالك بن أنس rو V V V، الموطأ تحقيق: محمد فؤاد عبد الباقي، دار إحياء

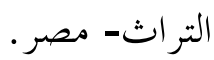


بr- الماوردي: علي بن محمد: الحاوي الكبير، بيروت، دار الكتب العلمية، .$p 199 \varepsilon$

بr- النفراوي: الفواكه الدواني: أحمد بن غنيم بن سلم النفراوي الملكي ت

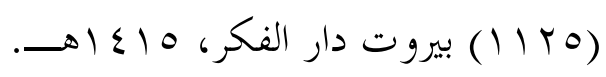

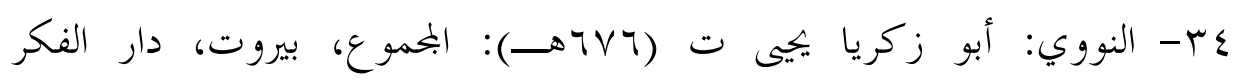
. $199 \mathrm{~V}$ هr- النووي: أبو زكريا ييىى ت (TVTهــ): روضة الطالبين. المكتب الإسلامي،

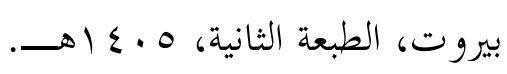
بr- يهيى الخطيب: يهيى عبد الرحمن عمر الخطيب، أحكام المرأة الحامل في الشريعة

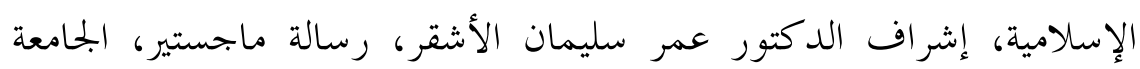

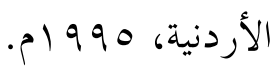


